\title{
Greener Pretreatment Approaches for the Valorisation of Natural Fibre Biomass into Bioproducts
}

\author{
Mohd Nor Faiz Norrrahim 1,2,*(D), Muhammad Roslim Muhammad Huzaifah ${ }^{3, *(\mathbb{D} \text {, }}$ \\ Mohammed Abdillah Ahmad Farid ${ }^{2, *}$, Siti Shazra Shazleen ${ }^{4}\left(\mathbb{0}\right.$, Muhammad Syukri Mohamad Misenan ${ }^{5}$, \\ Tengku Arisyah Tengku Yasim-Anuar ${ }^{6}$, Jesuarockiam Naveen ${ }^{7}$, Norizan Mohd Nurazzi ${ }^{8, * \mathbb{C} \text {, }}$

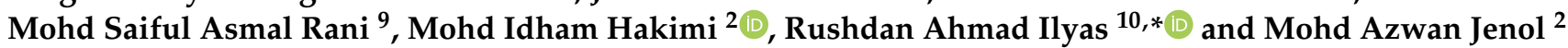

Citation: Norrrahim, M.N.F.; Huzaifah, M.R.M.; Farid, M.A.A. Shazleen, S.S.; Misenan, M.S.M.; Yasim-Anuar, T.A.T.; Naveen, J.; Nurazzi, N.M.; Rani, M.S.A.; Hakimi, M.I.; et al. Greener Pretreatment Approaches for the Valorisation of Natural Fibre Biomass into Bioproducts. Polymers 2021, 13, 2971. https://doi.org/10.3390/ polym 13172971

Academic Editor: Emin Bayraktar

Received: 8 August 2021

Accepted: 27 August 2021

Published: 31 August 2021

Publisher's Note: MDPI stays neutral with regard to jurisdictional claims in published maps and institutional affiliations.

Copyright: (c) 2021 by the authors Licensee MDPI, Basel, Switzerland. This article is an open access article distributed under the terms and conditions of the Creative Commons Attribution (CC BY) license (https:/ / creativecommons.org/licenses/by/ $4.0 /)$.
1 Research Center for Chemical Defence, Universiti Pertahanan Nasional Malaysia, Kem Sungai Besi, Kuala Lumpur 57000, Malaysia

2 Department of Bioprocess Technology, Faculty of Biotechnology and Biomolecular Sciences, Universiti Putra Malaysia UPM, Serdang 43400, Malaysia; idhamhakimi@ymail.com (M.I.H.); azwan.jenol@gmail.com (M.A.J.)

3 Faculty of Agricultural Science and Forestry, Bintulu Campus, Universiti Putra Malaysia, Bintulu Sarawak 97000, Malaysia

4 Laboratory of Biopolymer and Derivatives, Institute of Tropical Forestry and Forest Products (INTROP), Universiti Putra Malaysia UPM, Serdang 43400, Malaysia; shazra.shazleen@yahoo.com

5 Department of Chemistry, College of Arts and Science, Yildiz Technical University, Davutpasa Campus, Esenler, Istanbul 34220, Turkey; syukrimisenan@gmail.com

6 Nextgreen Pulp \& Paper Sdn. Bhd., Menara LGB, Jalan Wan Kadir, Taman Tun Dr. Ismail, Kuala Lumpur 60000, Malaysia; tengkuarisyah@gmail.com

7 School of Mechanical Engineering, Vellore Institute of Technology, Vellore 632014, India; gandhi.naveen66@gmail.com

8 Center for Defence Foundation Studies, Universiti Pertahanan Nasional Malaysia, Kem Perdana Sungai Besi, Kuala Lumpur 57000, Malaysia

9 School of Materials and Mineral Resources Engineering, Engineering Campus, Universiti Sains Malaysia, Nibong Tebal 14300, Malaysia; saifulasmal@gmail.com

10 School of Chemical and Energy Engineering, Faculty of Engineering, Universiti Teknologi Malaysia UTM, Johor Bahru 81310, Malaysia

* Correspondence: faiznorrahim@gmail.com (M.N.F.N.); muhammadhuzaifah@upm.edu.my (M.R.M.H.); abdillah.upm@gmail.com (M.A.A.F.); mohd.nurazzi@gmail.com (N.M.N.); ahmadilyas@utm.my (R.A.I.)

\begin{abstract}
The utilization of lignocellulosic biomass in various applications has a promising potential as advanced technology progresses due to its renowned advantages as cheap and abundant feedstock. The main drawback in the utilization of this type of biomass is the essential requirement for the pretreatment process. The most common pretreatment process applied is chemical pretreatment. However, it is a non-eco-friendly process. Therefore, this review aims to bring into light several greener pretreatment processes as an alternative approach for the current chemical pretreatment. The main processes for each physical and biological pretreatment process are reviewed and highlighted. Additionally, recent advances in the effect of different non-chemical pretreatment approaches for the natural fibres are also critically discussed with a focus on bioproducts conversion.
\end{abstract}

Keywords: non-chemical pretreatment; lignocellulosic biomass; bioproducts

\section{Introduction}

Many industries currently produce many tons of agro-industrial wastes. However, direct utilization of lignocellulosic biomass as a feedstock for bioproducts is challenging due to their complex structure (as represented in Figure 1). A variety of useful components, including sugars, protein, lipids, cellulose, and lignin, are present in natural fibres. The major issue that limits their utilization is, however, the tight bonding within their components [1]. Cross-linking of polysaccharides and lignin occurs through ester and ether bonds, while microfibrils produced by cellulose, hemicellulose, and lignin aid in the stability of 
plant cell wall structure [2,3]. These strong cross-linking connections exist between the components of the plant cell wall that act as a barrier to its disintegration.
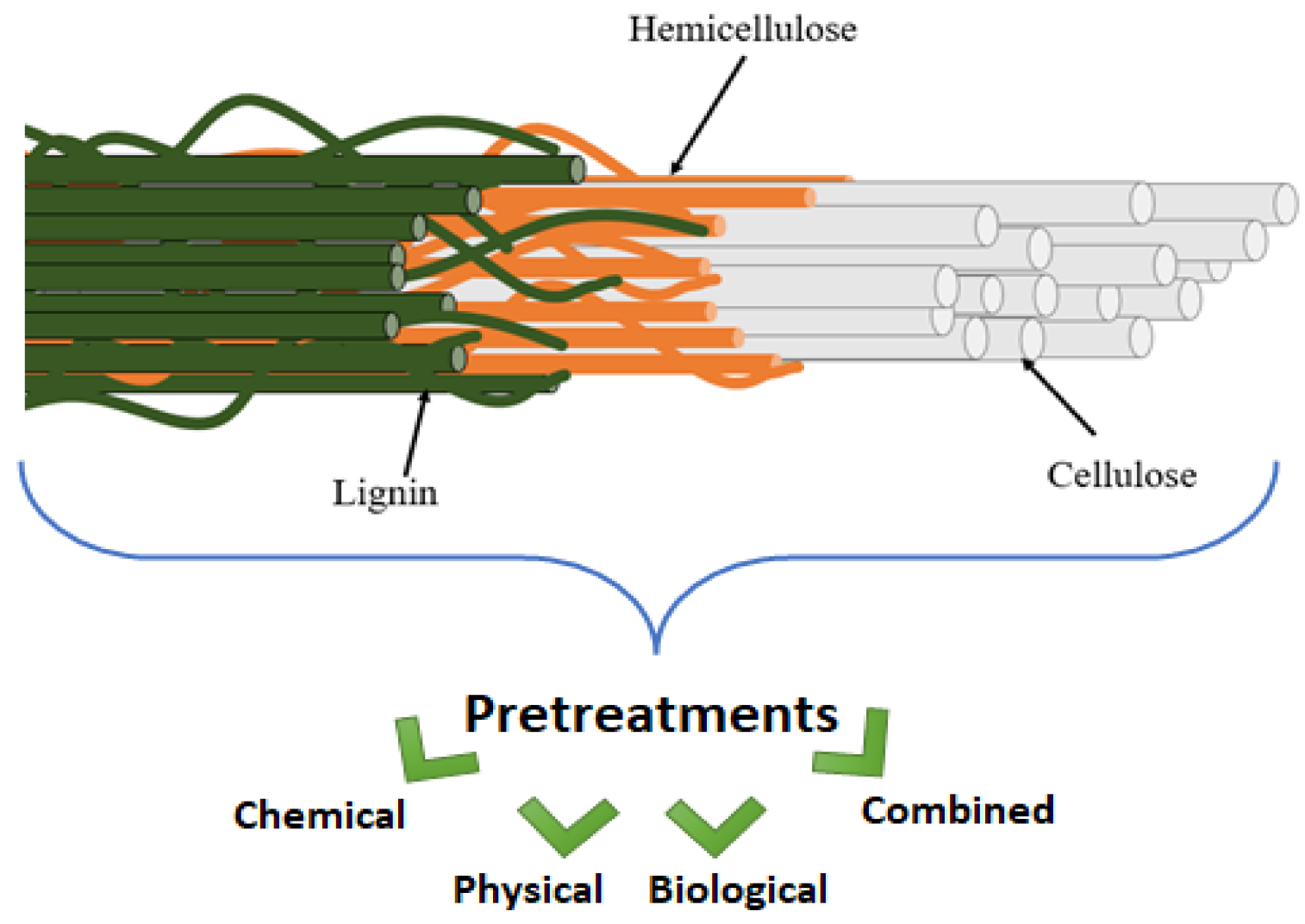

Figure 1. Overview of the complex structure of natural fibers and pretreatments.

Pretreatment helps to fractionate biomass prior to further processes, making it simpler to handle in the process [4-6]. It enables biomass hydrolysis and makes building blocks for biobased products, fuels, and chemicals. It is often the initial stage of the biorefining process and enables the following steps such as enzymatic hydrolysis and fermentation to be carried out more quickly, effectively, and economically [7]. The pretreatment method used is entirely dependent on the targeted application. Numerous pretreatment methods are mainly developed to effectively separate these interconnected components in order to get the most advantages from the lignocellulosic biomass's constituents.

Pretreatment of natural fibres is not as straightforward as it may seem. In fact, it is the second most expensive procedure after the installation of a power generator. Hydrogen bond disruption, cross-linked matrix disruption, as well as increased porosity and surface area, are the three objectives that a good pretreatment technique accomplishes in crystalline cellulose. Additionally, the result of pretreatment varies attributed to the different ratios of cell wall components [8]. More criteria to take into consideration for efficient and economically feasible pretreatment process include less chemical usage, prevention of hemicellulose and cellulose from denaturation, minimum energy demand, low price, and the capacity to reduce size.

Biomass recalcitrance is a term used for the ability of natural fibres to resist chemical and biological degradation. While there are many components involved in the recalcitrance of lignocellulosic biomass, the crystalline structure of cellulose, the degree of lignification, accessible surface area (porosity), the structural heterogeneity, and complexity of cellwall are primary causes $[9,10]$. As a consequence of breaking the resistant structure of lignocellulose, it causes lignin sheath, hemicellulose, and crystallinity to all be degraded, as well as casuing a decrease in cellulose's degree of polymerization [11]. 
Depending on the types of natural fibres employed, the preference for the pretreatment method varies according to the composition of cellulose, hemicellulose, and lignin. Figure 2 depicts the general differences between the many common approaches which come under the four categories of physical, chemical, biological, and combination pretreatment [4]. While some of these methods have successfully transitioned from a research platform to an industrial stage, there are many hurdles, and one of the greatest is the requirement for highly toxic waste generation and high-energy inputs. From here, a serious issue that must be addressed is the lack of green and cost-effective solutions. Nevertheless, it has only lately garnered significant attention as a potential solution to the problem by focusing on the employment of nonchemical pretreatment. This could be reflected by the increment in article publications that reviewed lignocellulosic fibre pretreatment via individual greener approach as highlighted in Table 1 indicating that this topic is increasingly well-known owing to environmental concerns. The development of technology that maximises the use of raw resources, reduces waste, and avoids the use of poisonous and hazardous compounds is critical to accomplishing this objective. However, a review of all greener pretreatment approaches for lignocellulosic biomass is missing in the current literature.

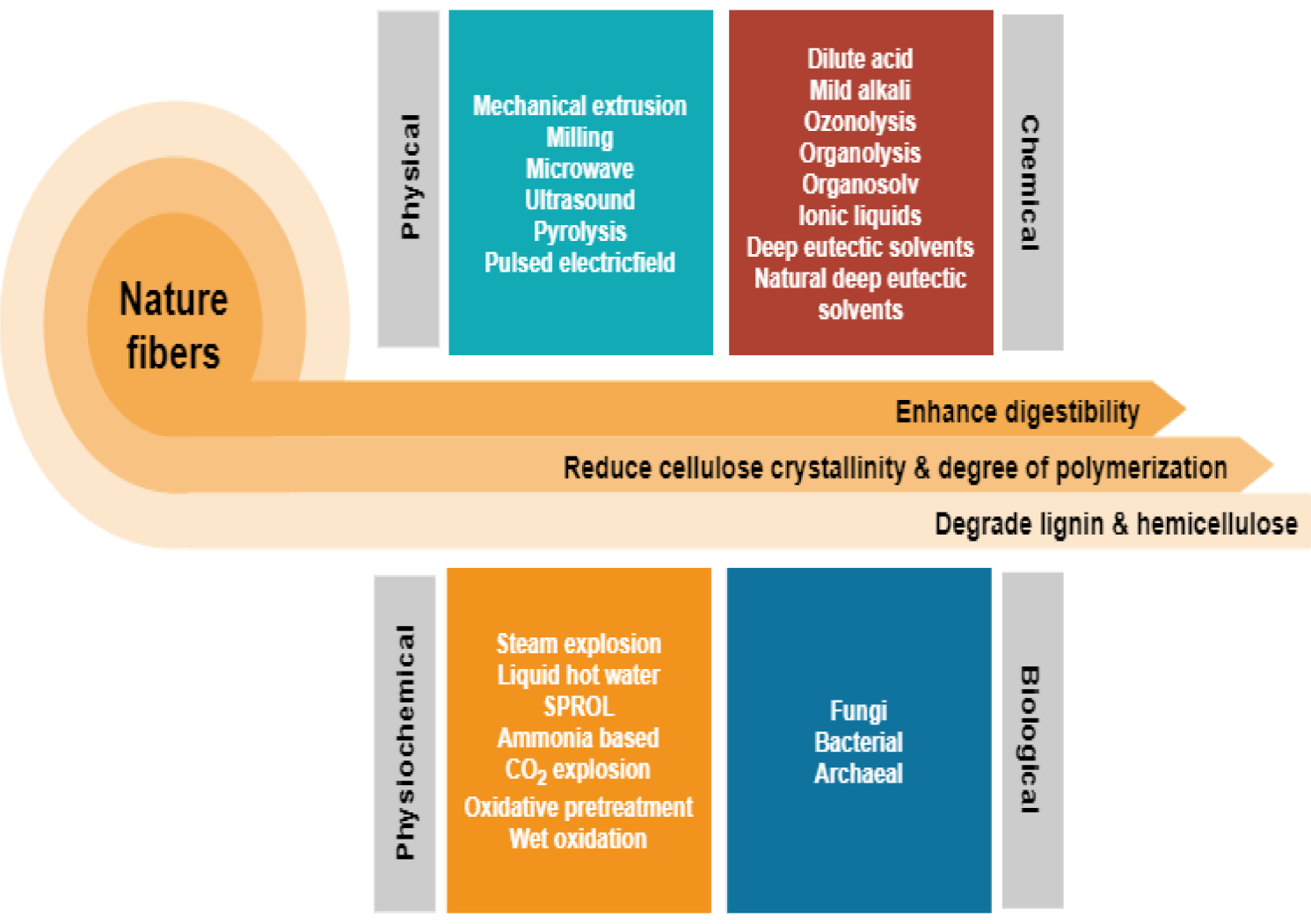

Figure 2. Different pretreatments, which fall into four main categories: physical, chemical, biological, and combination have been used to improve lignocellulosic fractionation for natural fibres. 
Table 1. Recent review articles related to greener pretreatment approaches for lignocellulosic biomass.

\section{No.} Title production-A review

A review on the environment-friendly emerging techniques for pretreatment of lignocellulosic biomass: Mechanistic insight and advancemen

Recent Insights into Lignocellulosic Biomass Pyrolysis: A Critical Review on Pretreatment, Characterization, and Products Upgrading

Recent advances in the pretreatment of lignocellulosic biomass for biofuels and value-added products
- $\quad$ Reviews the anaerobic digestion process, challenges in degrading lignocellulosic materials, the current status of research to improve the biogas rate and yield from the anaerobic digestion of lignocellulosic biomass via enzymatic pretreatment, and the future trend in research for the reduction of enzymatic pretreatment cost

- Discusses the important aspects of the emerging pretreatment techniques of lignocellulosic biomass including the advancements, and the mechanistic insight for large scale of commercial implementation in a lignocellulosic biorefinery.

- Provides an outline of the pyrolysis process including physical and chemical pretreatment of biomass, pyrolysis mechanism, and process products upgrading.

- Briefly presents recent findings on the chemical pretreatment for the conversion of lignocellulosic materials into fuel and value-added products.

- $\quad$ Reviews the application of emerging technologies in chemical and mechanical pretreatment. 
Hence, the green pretreatment approaches for lignocellulosic biomass such as physical, biological, and combination methods, as well as their impact on the separation of the complex components of different lignocellulosic sources, are reviewed in more detail in the next sections.

\section{Physical Pretreatment}

The physical pretreatment allows increasing the specific surface area of the fibres via mechanical comminution. It also contributes to reduce the crystallinity of the natural fibres and enhance their digestibility. The physical pretreatment usually does not affect the chemical composition of natural fibres. Physical pretreatment can be conducted by using milling, extrusion and ultrasound. Physical pretreatment is often an essential step prior to or following chemical or biochemical processing. However, the information on the mechanism of how physical pretreatment modifies the structures of the fibre is still limited.

There are some drawbacks of physical pretreatment that need to be considered. Physical pretreatment lacks the ability to remove the lignin and hemicellulose which limits the enzymes' access to cellulose. Besides that, physical pretreatment requires high energy consumption which limits its large-scale implementation and environmental safety concerns.

\subsection{Mechanical Extrusion}

Mechanical extrusion is one of the most conventional methods of pretreatment [17]. In this pretreatment, the fibres are subjected to a heating process $\left(>300^{\circ} \mathrm{C}\right)$ under shear mixing. Due to the combined effects of high temperatures that are maintained in the barrel and the shearing force generated by the rotating screw blades, the amorphous and crystalline cellulose matrix in the biomass residues is disrupted. Besides that, extrusion requires a significant amount of high energy, making it a cost-intensive method and difficult to scale up for industrial purposes [17].

Temperature and screw speed of extrusion are the main important factors. Karunanithy and Muthukumarappan [18] studied the effect of these factors on the pretreatment of corn cobs. When pretreatment was carried out at different temperatures $(25,50,75,100$, and $\left.125^{\circ} \mathrm{C}\right)$ and different screw speeds $(25,50,75,100$, and $125 \mathrm{rpm})$, maximum concentration sugars were obtained at $75 \mathrm{rpm}$ and $125^{\circ} \mathrm{C}$ using cellulase and $\beta$-glucosidase in the ratio of 1:4, which were nearly 2.0 times higher than the controls.

\subsection{Milling}

Mechanical milling is used to reduce the crystallinity of cellulose. It can reduce the size of fibre up to $0.2 \mathrm{~mm}$. However, studies found that further reduction of biomass particles below $0.4 \mathrm{~mm}$ has no significant effect on the rate and yield of hydrolysis [17]. The type of milling and milling duration are important factors that influence the milling process. These factors can greatly affect the specific surface area, the final degree of polymerization, and a net reduction in cellulose crystallinity.

Wet disk milling has been a popular mechanical pretreatment due to its low energy consumption as compared to other milling processes. Disk milling enhances cellulose hydrolysis by producing fibres and more effective as compared to hammer milling which produces finer bundles [19]. Hideno et al. [20] compared the effect of wet disk milling and conventional ball milling pretreatment method over rice straw. The optimal conditions obtained were $60 \mathrm{~min}$ of milling time in case of dry ball milling while 10 repeated milling operations were required in case of wet disk milling.

\subsection{Ultrasound}

Ultrasound is relatively a new technique used for the pretreatment of fibres [17]. Ultrasound waves affect the physical, chemical, and morphological properties of fibres. Ultrasound treatment leads to the formation of small cavitation bubbles. These bubbles can rupture the cellulose and hemicellulose fractions. The ultrasonic field is influenced by 
ultrasonic frequency and duration, reactor geometry, and types of solvent used. Besides that, fibres characteristics and reactor configuration also influence the pretreatment [21].

The power and duration of ultrasound are important to be optimised depending on the fibres and slurry characteristics. This is important to meet the pretreatment objectives. Duration of ultrasound pretreatment has maximum effect on pretreatment of fibres. Besides that, a higher ultrasound power level has an adverse effect on the pretreatment. It can lead to the formation of bubbles near the tip of the ultrasound transducer which hinders the transfer of energy to the liquid medium [22].

\section{Biological Pretreatment}

Retting is a biological process in which enzymatic activity removes non-cellulosic components connected to the fibre bundle, resulting in detached cellulosic fibres. The dew retting uses anaerobic bacteria fermentation and fungal colonization to produce enzymes that hydrolyse fibre-binding components on fibre bundles. Clostridium sp. is an anaerobic bacterium commonly found in lakes, rivers, and ponds. Plant stems were cut and equally scattered in the fields during the dew retting process, where bacteria, sunlight, atmospheric air and dew caused the disintegration of stem cellular tissues and sticky compounds that encircled the fibres [23]. For the dew retting procedure to enhance fungal colonization, locations with a warm day and heavy might dew are recommended.

Bleuze et al. [24] investigated the flax fibre's modifications during the dew retting process. Microbial colonization can be affected the chemical compositions of cell walls. After seven days, fungal hyphae and parenchyma were found on the epidermis and around fibre bundles, respectively. After the retting process (42 days), signs of parenchyma deterioration and fibre bundle decohesion revealed microbial infestation at the stem's inner core.

Fila et al. [25] found 23 different varieties of dew-retting agent fungi in Southern Europe. All Aspergillus and Penicillium strains yield high-quality retted flax fibres, according to the researchers. Besides that, under field conditions, Repeckien and Jankauskiene [26] investigated the effects of fungal complexes on flax dew-retting acceleration. Cladosporium species variations with high colonization rates (25-29\%) have been identified as a good fungus for fibre separation. Most fungi survived on flax fed with fungal complex N-3, which contained six different fungal strains.

On a commercial scale, Jankauskiene et al. [27] optimised the dew retting method. Two fungal combinations were created and put to straw after the swath was pulled and returned. Furthermore, after spraying Cladosporium herbarum suspension during fibre harvesting, extremely high fibre separation was found.

\section{Bacterial and Fungi Interaction}

Fungi colonization is thought to be the most important enzymatic active mechanism for dew retting. Recent research has focused on the interplay of the bacterial and fungal communities during dew retting. The association between the chemical contents of hemp fibres and microbial population fluctuation during the retting process was investigated by Liu et al. [28]. In the first seven days, fungal colonization was discovered with very little bacteria. After 20 days, there was a gradually risen in bacterial attachments on the fibre surface, with fewer fungal hyphae. The area with the highest bacterial concentration was found to severely deteriorate. The phylogenetic tree for the bacterial and fungal population in dew-retting hemp fibres is shown in Figure 3. While Table 2 shows ultrastructural changes in hemp stems and fibres as a result of microbial activity during the retting process. 


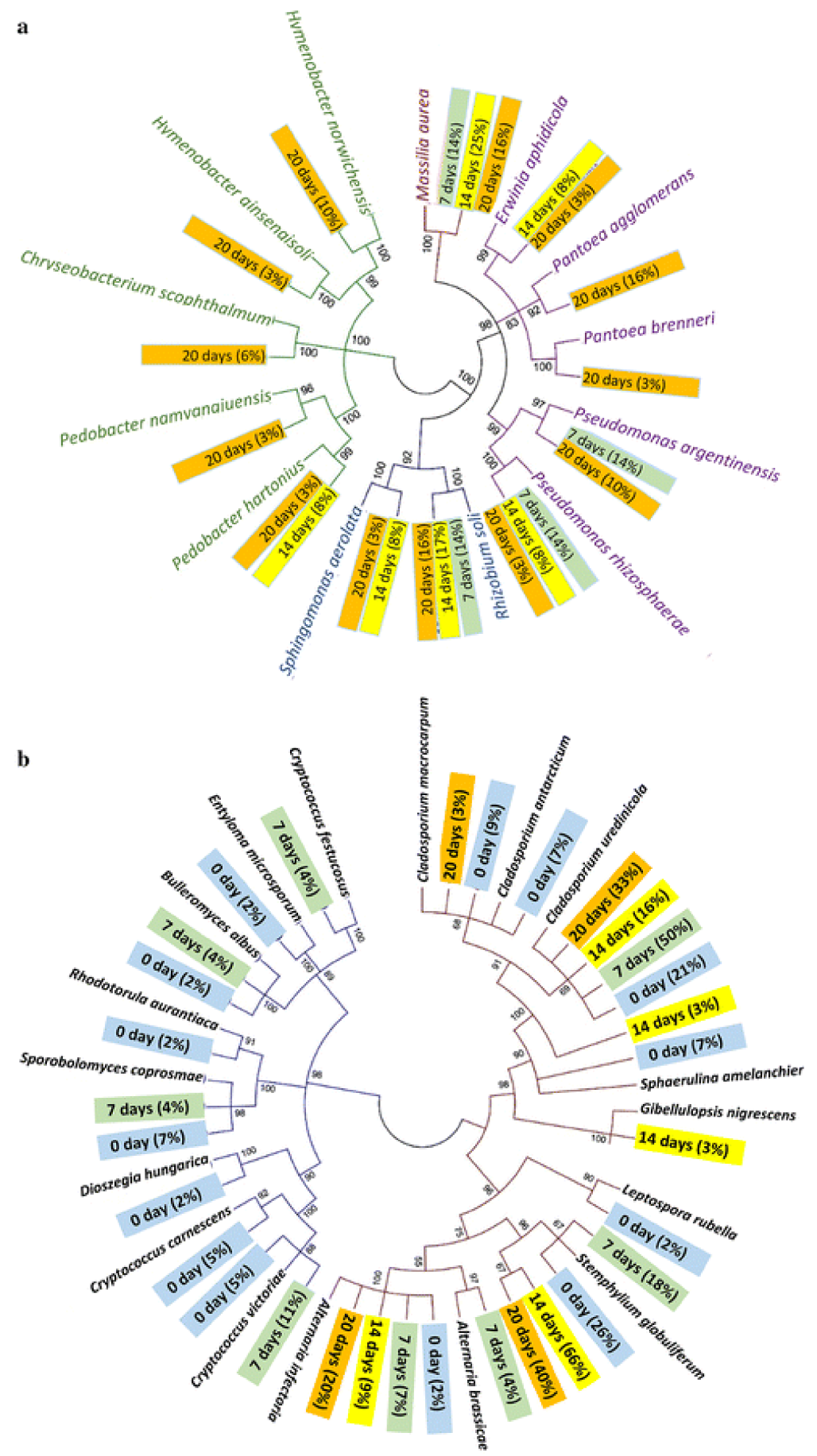

Figure 3. The phylogenetic tree of the (a) bacterial and (b) fungus communities found in hemp fibre samples. The color of the branches indicates the type of proteobacteria present, while the color of the tag indicates the number of bacteria/fungi present on different days [28]. 
Table 2. Highlights of ultrastructural changes on hemp stems and fibres associated with microbial activity during the retting process [29].

\section{Retting Period}

0 Days

7 Days

14-20 Days

(i) Cuticle has seriously deteriorated.

(i) Stem with a

well-preserved layered

(ii) Un-

(i) Un-collapsed, unbroken ells with their original cell geometry

Changes in the hemp stem's (iii) Living cells with and fibre's ultrastructure cytoplasm

(iv) Cuticle and trichomes are unharmed on the clear surface.

(v) Chloroplasts in

abundance in the upper

epidermis (i) The structure as a whole

is in good condition.

(ii) Fungal growth on the

inside the stems

(iii) With damaged

epidermis and parenchyma,

cellular architecture is less stable. outside of the stems and cells epidermis. completely, although moderate attacks (ii) Changes in cellular anatomy, as well as significant loss of live

(iii) Fibre bundles were isolated from each other and the

(iv) Thick-walled cells populate seldom: parenchyma degrades

chlorenchyma suffers less harm.

(v) Bast fibres with sporadic

vi) Fungi colonisation and decay morphology were both affected by fibre morphology.

\section{Fungi}

Fungi

(i) Mycelia with sparse

growth

(ii) Less variety

(iii) Outside of the cortical

layers, colonisation occurs

largely in live cells.

The dynamics and activity

Fungi

of microbes

(ii) Not observed Fungi (iv) Trichomes near to th

surface trichomes have

(v) Dependence on readily

(v) Dependence

(vi) Damage to cell walls is

(vi) Dam

reduced.

Bacteria
(i) Less abundant (i) Extensive and plentiful

(ii) Mycelia densely covering

the cuticle

(iii) diverse population

(iv) a large number of spores

v) Interactions and activities

that are intense

Bacteria

(i) Abundant

(ii) Diverse population

iii) Over the cuticle, colonies

(iv) Associated with hyphae

and fungal spores

(v) After 20 days, there are more

noticeable activity

(vi) Cuticle has severely deteriorated

\section{After 50 Days}

(i) The structure of hemp was severely harmed and dissolved.

(ii) The epidermis and cambium were heavily invaded by dominating bacteria.

(iii) In the bast regions, the parenchyma cells have been destroyed, and the structural integrity has been lost.

(iv) All cell types, including fibre cells, have hyphae inside their lumina.

(v) BFIs are more intense inside the stem.

.

(vii) Bast fibres with a thick wall and degradation properties

(viii) Effects on the ultrastructure of the fibre wall.

- CML loosening/degradation, resulting in delamination and defibration

- The S3 layer is loosening and decaying

- Delamination within the S2 trans wall and intra wall cracks in the S2 layer have a noticeable effect

- $\quad$ S2 materials have been removed directly (e.g., S2 thinning, broken $\mathrm{S} 2$, and disintegration into nanosized cellulose fibrillar structures)

Fungi

(i) Less abundant on the outside of the stem

(ii) Mycelia on the surface is dead, but there are active hyphae inside the

(iii) Mycelia, an invading bacteria's sole source of nourishment, showed bacterial mycophagy (i.e, extracellular and endocellular biotrophic and extracellular necrotrophic activities)

Bacteria

(i) Highly abundant inside and outside the stems

(ii) Highly dominant and diverse role.

(iii) Visible as dense overlay representing

(a) Biofilms

(b) Morphologically differen

colonies

(c) Randomly scattered cells

(iv) Showed strong BFIs

(v) Using fungal highways, bacterial movement occurs over and inside the hemp stem.

(vi) Cutinolytic and cellulolytic activities were improved. 


\section{Combination Pretreatment}

It can be noticed from the green pretreatment techniques applied to pretreat the lignocellulosic biomass reviewed in the previous section that, while each pretreatment method makes a significant contribution, no single pretreatment approach yields efficient results without its own inherent limitations. Therefore, the combined pretreatment strategies could minimise the drawbacks while still achieving the intended result.

\subsection{Physiochemical Pretreatment}

Physiochemical pretreatment could be achieved by temperature elevation and irradiation in the processing of lignocellulosic material. Physiochemical pretreatment by steam such as superheated steam, hydrothermal and steam explosion is the most common pretreatments applied on natural fibre for several purposes. Physiochemical pretreatment is usually applied to remove the hemicellulose and lignin from the natural fibres [30].

\subsubsection{Superheated Steam}

Pretreatment of fibres by superheated steam is gaining interest recently, as this pretreatment is considered as an environmentally friendly technique to remove hemicellulose. This could be a great alternative to chemical pretreatment in order to isolate the cellulose. Superheated steam is believed as the most economical pretreatment as compared to the other physical pretreatments as discussed before.

Superheated steam is unsaturated (dry) steam generated by the addition of heat to saturated (wet) steam [31]. It has several advantages such as improved energy efficiency, higher drying rate, being conducted at atmospheric pressure and reduced environmental impact when condensate is reused [32,33]. Saturated steam cannot be superheated when it is in contact with water which is also heated, and condensation of superheated steam cannot occur without being reduced to the temperature of saturated steam. It has a high heat transfer coefficient, enabling rapid and uniform heating. Drying rates with superheated steam are faster than those with conventional hot air. Steam in a dried state or superheated steam is assumed to behave like a perfect gas. Although superheated steam is considered a perfect gas, it possesses properties like those of gases namely pressure, volume, temperature, internal energy, enthalpy and entropy. The pressure, volume, and temperature of steam as a vapour is not connected by any simple relationship such as is expressed by the characteristic equation for a perfect gas. Figure 4 shows the schematic diagram of superheated steam pretreatment. The saturated steam was generated in the boiler. The saturated steam produced was further heated by a super-heater to produce superheated steam. Then, the superheated steam was subjected to the fibres.

Superheated steam has been managed to alter the chemical composition of natural fibres. It has been proven that superheated steam pretreatment managed to remove high amount of hemicellulose from the lignocellulose fibres [34-40]. According to Warid et al. [40], superheated steam pretreatment on oil palm biomass at higher temperature and shorter time managed to remove a high amount of hemicellulose while maintaining the cellulose composition as compared to the method reported by Norrrahim et al. [39]. It was found that oil palm mesocarp fibre pretreated at $260^{\circ} \mathrm{C} / 30 \mathrm{~min}$ managed to remove hemicellulose of $68 \%$, while cellulose degradation is maintained below $5 \%$. Besides that, superheated steam was also able to remove silica bodies from the fibres where the presence of silica bodies increases the difficulty in grinding the fibre and causes abrasive wear and screw damage [32]. 


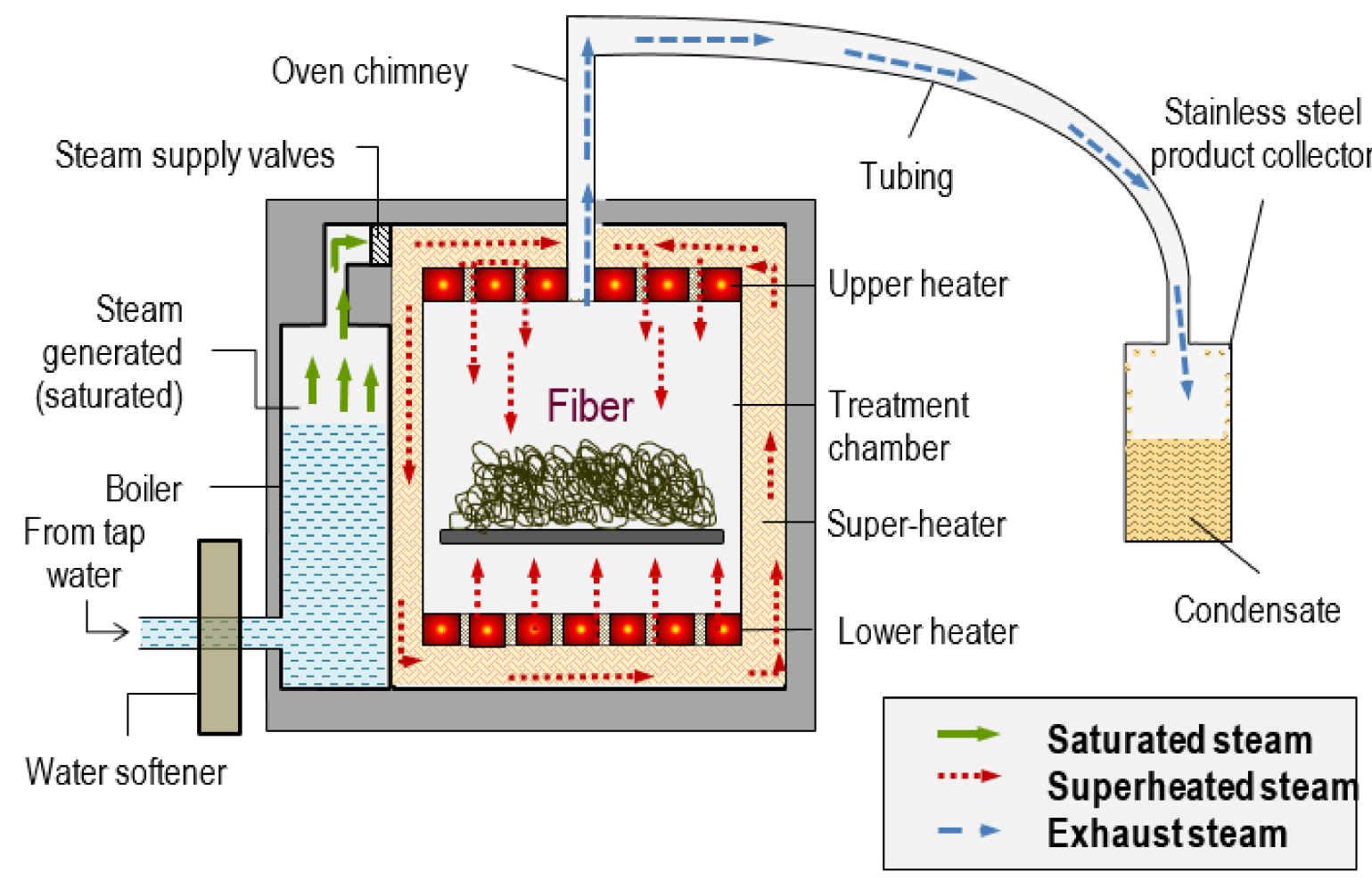

Figure 4. Schematic design of superheated steam pretreatment. Reprinted with permission from ref. [31]. 2018 Universiti Putra Malaysia.

\subsubsection{Hydrothermal}

Hydrothermal treatment is another pretreatment that has been proven to effectively remove impurities such as hemicellulose, lignin, and silica from lignocellulosic biomass. This treatment is being widely used in industry, owing to its low cost of production, high effectiveness in removing impurities without affecting the cellulose structure, disorganizing hydrogen bonds, swelling of the lignocellulosic biomass, as well as minimum requirements of preparation and handling [41,42]. In contrast to the superheated steam system that uses steam as the main mechanism, hydrothermal pretreatment only relies on water that will be subjected to a high temperature during the whole processing [43]. This treatment is also considered as an autohydrolysis of lignocellulosic linkages, with the presence of hydronium ions $\left(\mathrm{H}_{3} \mathrm{O}^{+}\right)$generated from water and acetic groups released from hemicellulose. The hydronium ions $\left(\mathrm{H}_{3} \mathrm{O}^{+}\right)$will act as a catalyst to break down and loosen the lignocellulosic structure [41,44]. This then will improve the effectiveness of further treatments such as enzymatic hydrolysis for biosugar production [43] and anaerobic digestion for biomethane production [45].

Numerous studies have reported the effectiveness of this treatment in reducing impurities, especially at a very high temperature. Zhang et al. [46] studied the effects of different hydrothermal temperatures which were 170,190 , and $210^{\circ} \mathrm{C}$ at 20 min pretreatment time on corn stover. This study reported a drastic reduction in hemicellulose with an increase in hydrothermal temperature. In fact, no content of hemicellulose was detected and almost $125 \%$ of lignin was removed after hydrothermal treatment at $210^{\circ} \mathrm{C}$. Similarly, Phuttaro et al. [47] also reported the same trend of results, in which no amount of hemicellulose was detected in Napier grass after pretreatet at $200^{\circ} \mathrm{C}$ for $15 \mathrm{~min}$. Both studies agreed that hydrothermal pretreatment plays a significant effect in improving the enzymatic hydrolysis yield afterwards. Meanwhile, Lee and Park [42] reported that sunflower biomass treated with hydrothermal pretreatment at $160-220^{\circ} \mathrm{C}$ for $30 \mathrm{~min}$ demonstrated a reduction of hemicellulose and lignin up to 25 and $15 \%$, respectively. This then led to higher methane yield (213.87-289.47 $\left.\mathrm{mL} \mathrm{g}^{-1}\right)$ and biodegradability (43-63\%) than the 
non-hydrothermally treated biomass. All of these reviews highlighted that despite of using a simple mechanism, hydrothermal can still efficiently removed impurities and improve the chemical and physical properties of lignocellulosic biomass prior to further treatments.

\subsubsection{Steam Explosion}

Steam explosion involves the use of high pressure and heat to pretreat lignocellulosic biomass. The biomass will be subjected to heat ranging from $160-280{ }^{\circ} \mathrm{C}$ and high pressure ranging from $0.2-5 \mathrm{MPa}$, depending on biomass source, duration, and other conditions $[48,49]$. Before the discovery of superheated steam and hydrothermal treatment, the steam explosion was widely applied in the industry due to its low energy consumption and chemical usage [49]. Figure 5 shows an example of the steam explosion process. Theoretically, biomass needs to be subjected to high temperature and pressure in a close reactor. The water contained in the biomass will then be evaporated and expanded, led to hydrolysis to a certain extent. Explosive decompression will then occur by promptly reducing the pressure to the atmospheric level $[50,51]$.

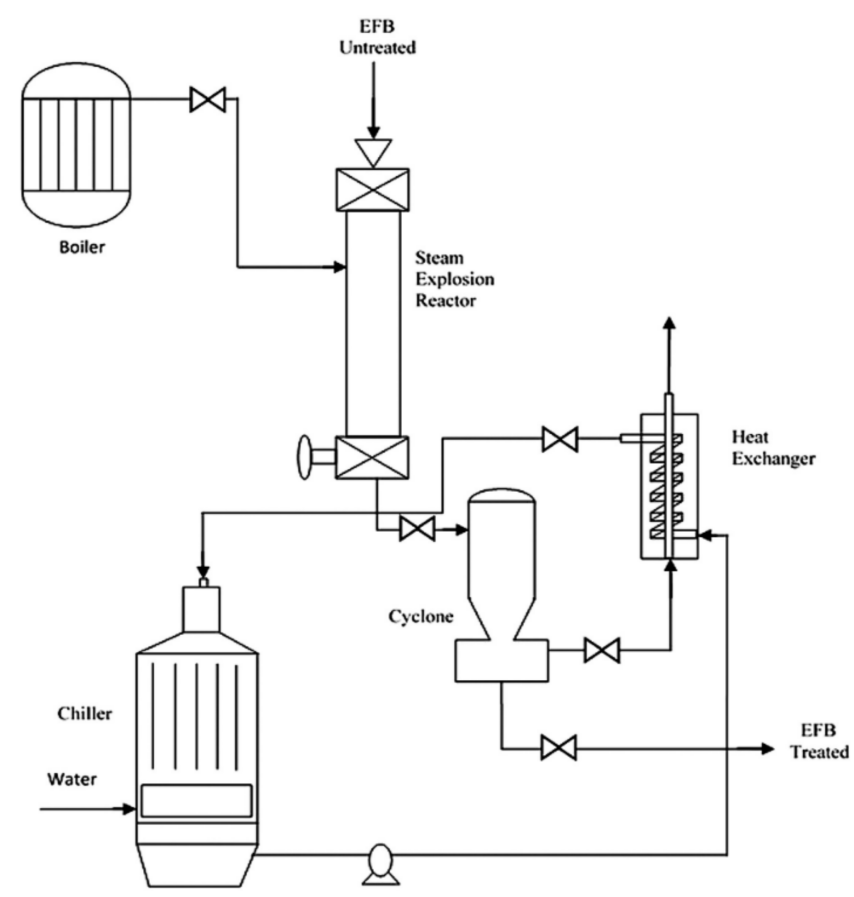

Figure 5. Schematic diagram of steam explosion process. Page: 11 Reprinted with permission from ref. [51]. 2016 Elsevier.

Steam explosion treatment helps to reduce the particle size of biomass, disrupt the structure of lignocellulosic biomass by removing amorphous structures such as hemicellulose and other impurities, and reduce cellulose crystallinity [52]. Similar to hydrothermal, the steam explosion also carried out auto-hydrolysis. During processing, acetic acids and other organic acids will be formed, and this will assist in the breakdown of ester and ether bonds in the cellulose-hemicellulose-lignin matrix. For steam explosion, reaction temperature, pressure, and processing duration are considered as the key factors.

Numerous studies have reported the effectiveness of this treatment in reducing impurities and enhancing the effectiveness of further treatments. For example, Abraham et al. [52] discovered that the sudden pressure drop due to explosion has pre-defibrillated the raw banana, jute, and pineapple leaf fibre biomass after pretreated for $1 \mathrm{~h}$, which then eases and enhances the efficiency of fibrillation process by acid hydrolysis for the production of nanocellulose. Meanwhile, Medina et al. [51] discovered an application of steam explosion pretreatment for empty fruit bunches. The heating time was around $2 \mathrm{~min}$ and the reaction time was controlled after the temperature was reached. It was found 
that the application of steam explosion helped to enhance the production of glucans to $34.69 \%$, reduce the amount of hemicellulose to $68.11 \%$, and increase enzymatic digestibility to $33 \%$. This was all due to steam explosion pretreatment, which helped in increasing the fibre porosity of empty fruit bunches. Marques et al. [53] also highlighted that the oil palm mesocarp fibre which has been treated to the steam explosion has higher purity, thermal stability, and crystallinity than the non-treated biomass. The reaction time was between 3 to $17 \mathrm{~min}$. The cellulose pulp yield was increased by $47 \%$. In addition, high-quality lignin was obtained as a co-product of steam explosion pretreatment, which can potentially be used for other purposes such as in the development of resin.

\subsection{Biological-Chemical Pretreatment}

In recent years, a more often used combined pretreatment method is physical and chemical combined pretreatment, while biological and chemical combined pretreatment has yet to be thoroughly researched. Combining microbial and chemical pretreatments, for instance, is seen as a cost-effective technique for reducing pretreatment times, minimizing chemical usage and hence secondary pollution [54]. Table 3 listed different biological-chemical pretreatment approaches to pretreat lignocellulosic biomass. Till now, the biological-alkaline pretreatment for lignocellulosic biomass has been the most widely researched.

Table 3. Previous research on biological-chemical pretreatment approaches to pretreat lignocellulosic biomass. Data retrieved from Ref. [54].

\begin{tabular}{|c|c|c|c|c|c|}
\hline \multirow{2}{*}{ Substrate } & \multicolumn{2}{|l|}{ Conditions } & \multicolumn{3}{|c|}{ Component's Degradation (\%) } \\
\hline & 1st Step & 2nd Step & Lignin & Hemicellulose & Cellulose \\
\hline \multicolumn{6}{|c|}{ Biological—alkaline pretreatment } \\
\hline Corn stalks & Irpex lacteus $\left(28^{\circ} \mathrm{C}, 15 \mathrm{~d}\right)$ & $\begin{array}{l}0.25 \mathrm{M} \mathrm{NaOH} \text { solution } \\
\left(75^{\circ} \mathrm{C}, 2 \mathrm{~h}\right)\end{array}$ & 80 & 51.37 & 6.62 \\
\hline Populus tomentosa & Trametes velutina D10149 $\left(28^{\circ} \mathrm{C}, 28 \mathrm{~d}\right)$ & $\begin{array}{c}70 \%(v / v) \text { ethanol aqueous } \\
\text { solution containing } 1 \%(w / v) \\
\mathrm{NaOH}\left(75^{\circ} \mathrm{C}, 3 \mathrm{~h}\right)\end{array}$ & 23.08 & 22.22 & 18.91 \\
\hline \multirow{2}{*}{ Willow sawdust } & Leiotrametes menziesii $\left(27^{\circ} \mathrm{C}, 30 \mathrm{~d}\right)$ & \multirow{2}{*}{$1 \%(w / v) \mathrm{NaOH}\left(80{ }^{\circ} \mathrm{C}, 24 \mathrm{~h}\right)$} & 59.8 & 68.1 & 51.2 \\
\hline & Abortiporus biennis $\left(27^{\circ} \mathrm{C}, 30 \mathrm{~d}\right)$ & & 54.2 & 51.8 & 29.1 \\
\hline \multicolumn{6}{|c|}{ Biological-acid pretreatment } \\
\hline Populus tomentosa & Trametes velutina $\mathrm{D} 1014\left(28^{\circ} \mathrm{C}, 56 \mathrm{~d}\right)$ & $1 \%$ sulphuric acid $\left(140{ }^{\circ} \mathrm{C}, 1 \mathrm{~h}\right)$ & 23.82 & 75.96 & (+) 18.74 \\
\hline $\begin{array}{l}\text { Oil palm empty fruit } \\
\text { bunches }\end{array}$ & Pleurotus floridanus LIPIMC996 $\left(31^{\circ} \mathrm{C}, 28 \mathrm{~d}\right)$ & $\begin{array}{l}\text { Ball milled at } 29.6 / \mathrm{s} \text { for } 4 \mathrm{~min} \text {. } \\
\text { Phosphoric acid treatment }\left(50^{\circ} \mathrm{C} \text {, }\right. \\
5 \mathrm{~h})\end{array}$ & $(+) 8.29$ & 60.63 & $(+) 37.52$ \\
\hline Olive tree biomass & Irpex lacteus (Fr.238 617/93) $\left(30^{\circ} \mathrm{C}, 28 \mathrm{~d}\right)$ & $2 \% w / v \mathrm{H}_{2} \mathrm{SO}_{4}\left(130^{\circ} \mathrm{C}, 1.5 \mathrm{~h}\right)$ & (+) 105.82 & 75.29 & (+) 62.95 \\
\hline \multicolumn{6}{|c|}{ Biological-oxidative pretreatment } \\
\hline Corn Straw & Echinodontium taxodii $\left(25^{\circ} \mathrm{C}, 15 \mathrm{~d}\right)$ & $\begin{array}{l}0.0016 \% \mathrm{NaOH} \text { and } 3 \% \mathrm{H}_{2} \mathrm{O}_{2} \\
\left(25^{\circ} \mathrm{C}, 16 \mathrm{~h}\right)\end{array}$ & 52.00 & 23.64 & (+) 45.45 \\
\hline Hemp chips & Pleurotus eryngii $\left(28^{\circ} \mathrm{C}, 21 \mathrm{~d}\right)$ & $\begin{array}{l}3 \% \mathrm{NaOH} \text { and } 3 \%(v / v) \mathrm{H}_{2} \mathrm{O}_{2} \\
\left(40{ }^{\circ} \mathrm{C}, 24 \mathrm{~h}\right)\end{array}$ & 55.7 & 23.2 & 25.1 \\
\hline \multicolumn{6}{|c|}{ Biological—organosolv pretreatment } \\
\hline Sugarcane straw & Ceriporiopsis subvermispora $\left(27^{\circ} \mathrm{C}, 15 \mathrm{~d}\right)$ & $\begin{array}{c}\text { Acetosolv pulping (Acetic acid } \\
\text { with } 0.3 \% w / w \mathrm{HCl})\left(120^{\circ} \mathrm{C}, 5 \mathrm{~h}\right.\end{array}$ & 86.8 & 93.8 & 32.1 \\
\hline Pinus radiata & Gloeophyllum trabeum $\left(27^{\circ} \mathrm{C}, 28 \mathrm{~d}\right)$ & $\begin{array}{l}60 \% \text { ethanol in water solvent } \\
\left(200^{\circ} \mathrm{C}, 1 \mathrm{~h}\right)\end{array}$ & 74.26 & 80.74 & - \\
\hline \multicolumn{6}{|c|}{ Biological-liquid hot water (LHW) pretreatment } \\
\hline Soybean & \multirow{2}{*}{$\begin{array}{l}\text { Liquid Hot water }\left(170^{\circ} \mathrm{C}, 3 \mathrm{~min}, 400 \mathrm{rpm}, 110 \mathrm{psi} \text {, }\right. \\
\text { solid to liquid ratio of } 1: 10)\end{array}$} & \multirow{2}{*}{$\begin{array}{c}\text { Ceriporiopsis subvermispora }\left(28^{\circ} \mathrm{C},\right. \\
18 \mathrm{~d})\end{array}$} & 36.69 & 41.34 & 0.84 \\
\hline Corn stover & & & 41.99 & 42.91 & 7.09 \\
\hline Wheat straw & \multirow{3}{*}{$\begin{array}{c}\text { Hot water extraction (HWE) }\left(85^{\circ} \mathrm{C}, 10 \mathrm{~min} \text {, solid }\right. \\
\text { to liquid ratio of } 1: 20)\end{array}$} & \multirow{3}{*}{$\begin{array}{c}\text { Ceriporiopsis subvermispora }\left(28^{\circ} \mathrm{C},\right. \\
18 \mathrm{~d})\end{array}$} & 24.87 & 13.19 & 1.86 \\
\hline Corn stover & & & 30.09 & 28.14 & 4.96 \\
\hline Soybean & & & 0.09 & 0.09 & 0.09 \\
\hline \multicolumn{6}{|c|}{ Biological—steam explosion pretreatment } \\
\hline Beech woodmeal & Phanerochaete chrysosporium $\left(37^{\circ} \mathrm{C}, 28 \mathrm{~d}\right)$ & Steam explosion $\left(215^{\circ} \mathrm{C}, 6.5 \mathrm{~min}\right)$ & 42.00 & - & - \\
\hline $\begin{array}{l}\text { Sawtooth oak, corn } \\
\text { and bran }\end{array}$ & Lentinula edodes (120 d) & $\begin{array}{c}\text { Steam explosion }\left(214{ }^{\circ} \mathrm{C}, 5 \mathrm{~min},\right. \\
20 \mathrm{~atm})\end{array}$ & 17.1 & 80.43 & (+) 5.19 \\
\hline
\end{tabular}

(+): represents the increment in fibre content. 


\section{The Influence of Pretreatment of Natural Fibre on Several Applications}

Pretreatment of lignocellulosic materials has long been known for its advantages. It has been applied for various applications such as biocomposites, adsorbent, paper, packaging, military, biosugars, biomedical, bioenergy and more [55-68]. In Table 4, the purposes of the non-chemical pretreatment strategies and their benefits and drawbacks are summarised [69]. Since there are so many pretreatment-related applications, discussing each pretreatment technique in depth becomes very challenging. For certain applications, pretreatment techniques applied on natural fibre are summarised in the following sections.

Table 4. Purposes of the pretreatment strategies and their advantages and disadvantages.

\begin{tabular}{|c|c|c|c|c|}
\hline Pretreatments & $\begin{array}{c}\text { Preferred } \\
\text { Natural Fibres }\end{array}$ & Purposes & Advantages & Disadvantages \\
\hline Physical & $\begin{array}{l}\text { Hardwoods and } \\
\text { agricultural } \\
\text { residues }\end{array}$ & $\begin{array}{l}\text { Enhance the digestibility } \\
\text { of lignocellulosic biomass } \\
\text { by increase the available } \\
\text { specific surface area, and } \\
\text { reduce both the degree of } \\
\text { polymerisation and } \\
\text { cellulose crystallinity }\end{array}$ & $\begin{array}{l}\text { (1) No recycling cost } \\
\text { (2) No chemical usage } \\
\text { (3) Increase biogas, } \\
\text { bioethanol and } \\
\text { biohydrogen yields }\end{array}$ & $\begin{array}{l}\text { (1) Excessive size reduction } \\
\text { decreases biofuel production } \\
\text { (2) Formation of fermentation } \\
\text { inhibitors at high temperature } \\
\text { (3) Incomplete digestion of } \\
\text { lignin-carbohydrate matrix } \\
\text { (4) The need to wash the } \\
\text { hydrolysate decreases sugar yield } \\
\text { (5) High energy requirement }\end{array}$ \\
\hline Biological & $\begin{array}{l}\text { Hardwoods, } \\
\text { softwoods, and } \\
\text { agricultural } \\
\text { residues }\end{array}$ & $\begin{array}{l}\text { Leverage the action of } \\
\text { fungi capable of } \\
\text { producing enzymes that } \\
\text { can degrade lignin, } \\
\text { hemicellulose, and } \\
\text { polyphenols }\end{array}$ & $\begin{array}{l}\text { (1) The depolymerisation } \\
\text { is very selective and } \\
\text { efficient } \\
\text { (2) Low-capital cost } \\
\text { (3) Low energy } \\
\text { requirement } \\
\text { (4) No chemicals } \\
\text { requirement } \\
\text { (5) Mild process } \\
\text { conditions }\end{array}$ & $\begin{array}{l}\text { (1) The rate of biological } \\
\text { pretreatment is too slow for } \\
\text { industrial purposes (10-14 days) } \\
\text { (2) Require careful growth } \\
\text { conditions and a large amount of } \\
\text { space } \\
\text { (3) A fraction of carbohydrate is } \\
\text { consumed by the microbes, thus } \\
\text { reduces the sugar yield }\end{array}$ \\
\hline
\end{tabular}

\subsection{Influence of Physical Pretreatment on Applications}

Physical pretreatment is responsible for the changes in specific surface area, particle sizes, crystallinity index, or polymerization degree of biomass. The physical pretreatment avoids the use of chemicals, thus reducing the generation of waste and inhibitors for subsequent reactions. The management of biomass after harvesting, storage, and transportation is made easier by a higher bulk density [70]. Reduced particle size and increased specific surface area facilitate the following process by establishing a phase barrier between lignocellulosic material and chemicals and eliminating heat transfer limitation [71]. Mechanical, microwave or ultrasound pretreatments are the most common techniques carried out to improve the efficiency of the main steps in biomass processing.

It has been discovered that milling leads to higher production of biogas, bioethanol, and biohydrogen. Given the high energy requirements of industrial milling and the increasing energy demand, it seems doubtful that milling will be economically viable [69]. While most studies demonstrated that milling after chemical pretreatment reduces the amount of energy used and the cost of solid-liquid separation, the amount of mixing in pretreatment slurries and fermentation inhibitors are avoided [72]. Thus, understanding the characteristics of the feedstock is critical for making the best choice of technique and equipment for mechanical processing, and this should guarantee an adequate costeffectiveness balance [73].

De la Rubia et al. [74] discovered that the excessive reduction in biomass may lower biofuel generation and impede methane synthesis during anaerobic digestion by the formation of inhibitory volatile fatty acids (VFA). When coupled with other pretreatment techniques, size reduction is more successful. The greatest biogas generation from rice straw 
was achieved via a combination of milling, grinding, and heating treatment. Milling is beneficial since it eliminates inhibitors of fermentation such as furfural and hydroxyl methyl furfural [75]. There have also been suggestions for other types of physical pretreatment, including the use of gamma rays to break the $\beta-1,4$ glycosidic linkages, which results in a higher surface area and a lower crystallinity [76]. Ball milling pretreatment gave the lowest particle size compared to mashing or chipping but resulted in a lower hydrolysis rate [77]. On a wide scale, this technique will certainly be extremely costly, and it will raise significant environmental and safety issues. The use of a twin-screw extruder for methane production may reduce $50 \%$ of hemicellulose content. This concomitantly increases the fraction of soluble chemicals, e.g., carbohydrates, proteins, lipids, minerals, and vitamins, and rapidly converted to $15-21 \%$ more biogas by methanogenic microorganisms [78]. Table 5 summarises the applications that used physical pretreatments and their yield improvement and product properties.

Table 5. A summary of physical pretreatments applied for numerous applications.

\begin{tabular}{|c|c|c|c|c|c|}
\hline Bioproducts & Natural Fibres & Pretreatments & Conditions & $\begin{array}{c}\text { Yield } \\
\text { Improvement/Product } \\
\text { Properties }\end{array}$ & References \\
\hline \multirow{2}{*}{ Biohydrogen } & Corn stover & $\begin{array}{c}\text { Steam } \\
\text { explosion }\end{array}$ & $\begin{array}{c}1.5 \mathrm{Mpa} \text { and } 198^{\circ} \mathrm{C} \text { for } \\
1.5 \mathrm{~min}\end{array}$ & $51.9 \mathrm{~L} \mathrm{H}_{2} \mathrm{~kg}^{-1} \mathrm{TS}^{*}$ & {$[79]$} \\
\hline & Rice straw & Hydrothermal & $\begin{array}{c}\mathrm{pH} 7.0,210^{\circ} \mathrm{C}, \\
15.4^{\circ} \mathrm{C} \min ^{-1} \text {, and } 20 \% \text { TS }\end{array}$ & $28.0 \mathrm{~mL} \mathrm{H}_{2} \mathrm{~g}^{-1} \mathrm{VS}$ * & [80] \\
\hline \multirow{6}{*}{ Biomethane } & $\begin{array}{l}\text { Sugarcane } \\
\text { bagasse }\end{array}$ & Hydrolysis & $\begin{array}{c}178.6^{\circ} \mathrm{C}, 43.4 \mathrm{~min} \text {, and solid } \\
\text { to liquid ratio of } 0.24\end{array}$ & $1.56 \mathrm{Nm}^{3} \mathrm{CH}_{*} \mathrm{~kg}^{-1} \mathrm{TOC}$ & [81] \\
\hline & Wheat straw & \multirow{2}{*}{$\begin{array}{l}\text { Microwave } \\
\text { irradiation }\end{array}$} & \multirow[b]{2}{*}{$260^{\circ} \mathrm{C}, 33$ bars, $3 \mathrm{~min}$} & $28 \%$ & [82] \\
\hline & $\begin{array}{l}\text { Pennisetum } \\
\text { hybrid }\end{array}$ & & & $12 \%$ & [83] \\
\hline & $\begin{array}{l}\text { Blend of maize, } \\
\text { ryegrass, and rice } \\
\text { straw }\end{array}$ & Extrusion & Exit slit opened at $60 \%$ & $11.5-13.4 \%$ & [84] \\
\hline & Hay & $\begin{array}{c}\text { Steam } \\
\text { explosion }\end{array}$ & $220^{\circ} \mathrm{C}$ for $15 \mathrm{~min}$ & $16 \%$ & [85] \\
\hline & $\begin{array}{l}\text { Vine trimming } \\
\text { shoot }\end{array}$ & Extrusion & $200 \mathrm{~g} \mathrm{~h}^{-1}$ feed rate & $\begin{array}{l}51-58 \% \text { hemicellulose } \\
\text { reduction, } 15.7-21.4 \% \\
\mathrm{CH}_{4} \text { increased }\end{array}$ & [78] \\
\hline \multirow{6}{*}{ Biosugar } & Wheat straw & $\begin{array}{l}\text { Supercritical } \\
\mathrm{CO}_{2} \text { \& steam } \\
\text { explosion }\end{array}$ & $\begin{array}{l}\text { A steam explosion at } 200^{\circ} \mathrm{C} \\
\text { for } 15 \mathrm{~min} \text { and supercritical } \\
\mathrm{CO}_{2} \text { of } 12 \mathrm{MPa} \text { at } 190^{\circ} \mathrm{C} \text { for } \\
60 \mathrm{~min}\end{array}$ & $36.5 \%$ & [86] \\
\hline & $\begin{array}{l}\text { Poplar wood } \\
\text { chips }\end{array}$ & $\begin{array}{l}\text { Mechanical } \\
\text { pulping \& } \\
\text { steam }\end{array}$ & $\begin{array}{l}\text { Disc clearance set } 0.5-0.1 \mathrm{~mm} \\
\text { for mechanical pulping and } \\
\text { steam pretreatment at } 210^{\circ} \mathrm{C} \\
\text { for } 5 \mathrm{~min}\end{array}$ & $76 \%$ & [87] \\
\hline & Poplar wood & $\begin{array}{c}\text { Steam } \\
\text { explosion }\end{array}$ & $180^{\circ} \mathrm{C}$ and $18 \mathrm{~min}$ & $94 \%$ & [88] \\
\hline & Cane bagasse & \multirow{3}{*}{ Hydrothermal } & $200^{\circ} \mathrm{C}$ & $4 \mathrm{mg}$ xylose $\mathrm{ml}^{-1} *$ & [89] \\
\hline & Pinewood & & $240{ }^{\circ} \mathrm{C}$ and $10 \mathrm{~min}$ & $32 \% * *$ & [90] \\
\hline & Rapeseed meal & & $260^{\circ} \mathrm{C}$ and $10 \mathrm{~min}$ & $51 \mathrm{~g}_{\text {glucose }} \mathrm{kg}^{-1 *}$ & [91] \\
\hline \multirow{4}{*}{ Nanocellulose } & Poplar wood & $\begin{array}{c}\text { Steam } \\
\text { explosion }\end{array}$ & $2 \mathrm{MPa}$ for $180 \mathrm{~s}$ & $13.2 \%$ & [92] \\
\hline & Cotton & \multirow{2}{*}{$\begin{array}{l}\text { High- } \\
\text { pressure } \\
\text { homogeniza- } \\
\text { tion }\end{array}$} & \multirow{2}{*}{$80 \mathrm{MPa}$ for $30 \mathrm{HPH}$} & $\begin{array}{l}10-20 \mathrm{~nm} \text { in diameter, } \\
\text { reduced thermal stability, } \\
\text { and crystallinity }\end{array}$ & [93] \\
\hline & $\begin{array}{l}\text { Sugarcane } \\
\text { bagasse }\end{array}$ & & & $\begin{array}{l}10-20 \mathrm{~nm} \text { in diameter, } \\
\text { reduced thermal stability, } \\
\text { and crystallinity }\end{array}$ & [94] \\
\hline & Oil palm biomass & $\begin{array}{l}\text { Superheated } \\
\text { steam }\end{array}$ & $260^{\circ} \mathrm{C}$ for $30 \mathrm{~min}$ & $\begin{array}{l}<100 \mathrm{~nm} \text { diameter, } 27 \% \\
\text { crystallinity reduced }\end{array}$ & [35] \\
\hline
\end{tabular}

* The highest yield obtained. ${ }^{* *}$ In carbohydrate. 


\subsection{Influence of Biological Pretreatment on Applications}

The majority of pretreatment methods involve costly instruments or equipment that consumes a lot of energy, depending on the process. Biomass conversion in particular requires a large amount of energy for physical and thermochemical operations. Biological treatment with different kinds of rot fungus is being recommended more than ever as a low-energy delignification technique. The pretreatment is renowned for working with fungal and enzyme-assisted processes to break down the barrier that has formed within the cell wall, allowing for more abundant lignocellulosic components to be utilised in the activities of cellulase enzymes, hence increase their digestibility and yield. For instance, a pretreatment may enhance the enzymatic hydrolysis rate by 3-10-fold [1].

Additionally, any pretreatment should prevent carbohydrate degradation or loss, as well as the production of by-products that are detrimental to future hydrolysis and fermentation. The presence of white-rot fungus allows the organism to delignify, without compensating for the carbohydrate content, resulting in enhanced $30-35 \%$ cellulose conversion to sugar [95] and an additional 10-96\% methane production [96,97]. In contrast to thermochemical techniques, chemical pretreatment suffers from silica scaling that prohibits the recovery of alkaline chemicals, due to the high silica concentration of many agricultural feedstocks, such as rice and wheat straw. The economic feasibility of scaling up biological pretreatment is higher since it does not need a large initial capital investment due to the lack of or reduced use of chemicals and heat, as well as the absence of a necessity for feedstock size reduction [19]. A further disadvantage of the thermochemical method is that it often produces low-molecular-mass molecules with high pretreatment severities, which may act as an inhibitor to the primary process [98]. As a result, it needs a detoxification step after the thermochemical reaction, which adds to the cost [99].

Another possibility of biological pretreatment is the potential to produce a variety of value-added co-products or intermediates, including enzymes, reducing sugars, furfural, ethanol, protein and amino acids, carbohydrates, lipids, organic acids, phenols, activated carbon, degradable plastic composites, cosmetics, adsorbents, resins, medicines, foods and feeds, methane, pesticides, promoters, secondary metabolites, surfactants, fertiliser, and other miscellaneous products [100-104]. Despite many successful attempts, economic separation and co-products recovery have remained a problem. Nonetheless, the diversity of the product allows for a wide range of markets, which means that market saturation is less of a concern [97].

Despite the advantage of requiring no additional nutrients, the usual fungal breakdown process needs a lengthy incubation period of up to 14-56 days [105]. Carbohydrates also gradually degrade over this period, which results, even with selective lignin-degrading fungus, in a reduced sugar yield, therefore making fungal biological pretreatment is impracticable for use in industrial production. The use of enzymes rather than fungus may overcome these significant drawbacks, including less carbohydrate consumption, shorter treatment time, and better yield [106]. However, only a limited number of enzyme treatments are as efficacious in pulping as fungal treatments, since solid wood enzymes cannot penetrate effectively and need high pressure to get better results [97]. Table 6 summarises the applications that used biological pretreatments and their yield improvement and product properties. 
Table 6. A summary of biological pretreatments applied for numerous applications.

\begin{tabular}{|c|c|c|c|c|c|}
\hline Bioproducts & Natural Fibres & Type of Microbes/Enzymes & $\begin{array}{l}\text { Hydrolysis } \\
\text { Conditions }\end{array}$ & $\begin{array}{l}\text { Yield Improve- } \\
\text { ment/Product } \\
\text { Properties }\end{array}$ & References \\
\hline Biohydrogen & Corn stover & $\begin{array}{l}\text { Clostridium cellulolyticum and } \\
\text { hydrogen fermentation bacteria }\end{array}$ & $\begin{array}{c}20 \mathrm{~mL} \text { of medium, } \\
5 \%(v / v) \text { inoculum, } \\
10 \mathrm{~g} \mathrm{~L}^{-1} \text { carbon } \\
\text { source, at } 37^{\circ} \mathrm{C} \text { for } \\
96 \mathrm{hrs}\end{array}$ & $40.3 \mathrm{~L} \mathrm{H}_{2} \mathrm{~kg}^{-1} \mathrm{TS}$ * & [79] \\
\hline \multirow{6}{*}{ Bioethanol } & Corn stover & Ceriporiopsis subvermispora & $28^{\circ} \mathrm{C}$ for 18 days & $\begin{array}{l}57.8 \% \text { yield } \\
\text { increased }\end{array}$ & [107] \\
\hline & Corn stover & Ceriporiopsis subvermispora & $28^{\circ} \mathrm{C}$ for 35 days & $\begin{array}{l}66.6 \% \text { yield } \\
\text { increased }\end{array}$ & [107] \\
\hline & $\begin{array}{l}\text { Potato and } \\
\text { cassava peel }\end{array}$ & $\begin{array}{l}\text { Gloeophyllum sepiarium and } \\
\text { Pleurotus ostreatus }\end{array}$ & $28^{\circ} \mathrm{C}$ for 7 days & $26 \%$ yield increased & [108] \\
\hline & Straw & $\begin{array}{c}\text { Neosartorya } \\
\text { fischeri-Myceliophthora } \\
\text { thermophila and Aeromonas } \\
\text { hydrophila-Pseudomonas poae }\end{array}$ & $30-55^{\circ} \mathrm{C}$ for 6 days & $\begin{array}{l}\text { 7-fold yield } \\
\text { increased }\end{array}$ & [109] \\
\hline & Corn stover & \multirow{2}{*}{ Irpex lacteus } & $28^{\circ} \mathrm{C}$ for 42 days & $\begin{array}{l}66.9 \% \text { yield } \\
\text { increased }\end{array}$ & [110] \\
\hline & Corn stalks & & $28^{\circ} \mathrm{C}$ for 28 days & $82 \%$ yield increased & [111] \\
\hline \multirow{4}{*}{ Biomethane } & Wheat straw & Trametes versicolor & $\begin{array}{l}\text { Laccase at } 500 \mathrm{U} / \mathrm{L}, \\
25^{\circ} \mathrm{C} \text { for } 6 \text { days }\end{array}$ & $\begin{array}{l}10-18 \% \text { yield } \\
\text { increase }\end{array}$ & [96] \\
\hline & Cassava & Yeast and cellulolytic bacteria & $\begin{array}{l}100 \mathrm{~mL} \text { of PCS } \\
\text { medium, at } 55^{\circ} \mathrm{C} \\
\text { for } 12 \mathrm{~h}\end{array}$ & $\begin{array}{l}96.6 \% \text { yield } \\
\text { increased }\end{array}$ & [112] \\
\hline & Microalgae & $\begin{array}{c}\text { Enzyme mix (cellulase, } \\
\text { glucohydrolase and xylanase) }\end{array}$ & $\begin{array}{l}1 \% \text { enzyme mix, } \\
37^{\circ} \mathrm{C} \text { for } 24 \mathrm{hrs}\end{array}$ & $15 \%$ yield increased & [113] \\
\hline & Sawdust & $\begin{array}{c}\text { Methanobrevibacter thaueri MB-1, } \\
\text { Methanosarcina acetivorans } \\
\text { MB-2, and Methanococcus voltae } \\
\text { MB 3. }\end{array}$ & $60^{\circ} \mathrm{C}$ for 6 days & $\begin{array}{l}92.2 \% \text { yield } \\
\text { increased }\end{array}$ & [114] \\
\hline \multirow{8}{*}{ Biosugar } & Corn stover & Ceriporiopsis subvermispora & $28^{\circ} \mathrm{C}$ for $5-7$ days & $\begin{array}{l}57-67 \% \text { yield } \\
\text { increase }\end{array}$ & [107] \\
\hline & Silver grass & $\begin{array}{c}\text { Bacillus, Pseudomonas, } \\
\text { Exiguobacterium, and Aeromonas }\end{array}$ & $37^{\circ} \mathrm{C}$ for 7 days & $\begin{array}{l}\text { 2.2-fold yield } \\
\text { increased }\end{array}$ & [115] \\
\hline & $\begin{array}{l}\text { Sugarcane } \\
\text { bagasse }\end{array}$ & Ceriporiopsis submervispora & $27^{\circ} \mathrm{C}$ for 60 days & $47 \%$ yield increased & [116] \\
\hline & Sawdust & Pleurotus pulmonarius & $28^{\circ} \mathrm{C}$ for 30 days & $\begin{array}{l}94.8 \% \text { yield } \\
\text { increased }\end{array}$ & [117] \\
\hline & Paddy straw & Pleurotus florida & $\begin{array}{l}25-29{ }^{\circ} \mathrm{C} \text { for } \\
28 \text { days }\end{array}$ & $\begin{array}{l}75.3 \% \text { yield } \\
\text { increased }\end{array}$ & [118] \\
\hline & \multirow[b]{2}{*}{ Rice straw } & Pholiota adiposa & $25^{\circ} \mathrm{C}$ for $120 \mathrm{~h}$ & $716 \mathrm{mg} \mathrm{g}^{-1 *}$ & [119] \\
\hline & & $\begin{array}{l}\text { Pholiota adipose and Armillaria } \\
\text { gemina }\end{array}$ & $27^{\circ} \mathrm{C}$ for 45 days & $\begin{array}{l}74.2 \% \text { yield } \\
\text { increased }\end{array}$ & [120] \\
\hline & $\begin{array}{c}\text { Populus } \\
\text { tomentiglandulosa }\end{array}$ & Armillaria gemina SKU2114 & $30^{\circ} \mathrm{C}$ for $48 \mathrm{~h}$ & $62 \%$ yield increased & [121] \\
\hline \multirow{6}{*}{ Nanocellulose } & Eucalyptus & $\begin{array}{l}\text { Endoglucanase and } \\
\text { cellobiohydrolase }\end{array}$ & $7 \mathrm{pH}, 50^{\circ} \mathrm{C}$ for $48 \mathrm{~h}$ & $\begin{array}{l}20 \mathrm{~nm} \text { diameter, } \\
>500 \mathrm{~nm} \text { length }\end{array}$ & [122] \\
\hline & Wood fibre & Endoglucanase & $4.8 \mathrm{pH}, 50^{\circ} \mathrm{C}$ for $2 \mathrm{~h}$ & 5-30 nm diameter & [123] \\
\hline & Orange residues & B-glucosidase & $4 \mathrm{pH}, 50{ }^{\circ} \mathrm{C}$ for $48 \mathrm{~h}$ & $\begin{array}{l}180 \mathrm{~nm} \text { diameter, } \\
1.3 \mathrm{~mm} \text { length }\end{array}$ & [124] \\
\hline & $\begin{array}{l}\text { Sugarcane } \\
\text { bagasse }\end{array}$ & $\begin{array}{l}\text { B-glucosidase and } \\
\text { endoglucanase }\end{array}$ & $5 \mathrm{pH}, 50^{\circ} \mathrm{C}$ for $24 \mathrm{~h}$ & $\begin{array}{l}\text { 14-18 nm diameter, } \\
195-250 \mathrm{~nm} \text { length }\end{array}$ & [125] \\
\hline & Maple pulp & $\begin{array}{l}\text { Cellic CTec } 2 \text { and Cellic HTec } 2 \\
\text { (commercial enzymes) }\end{array}$ & $\begin{array}{c}4.8 \mathrm{pH}, 50^{\circ} \mathrm{C} \text { for } \\
72 \mathrm{~h}\end{array}$ & $\begin{array}{l}\text { 5-10 nm diameter, } \\
1 \mu \mathrm{m} \text { length }\end{array}$ & [126] \\
\hline & Cotton linters & Cellulase & $5 \mathrm{pH}, 55^{\circ} \mathrm{C}$ for $24 \mathrm{~h}$ & $\begin{array}{l}35 \mathrm{~nm} \text { diameter, } \\
0.3 \mathrm{~mm} \text { length }\end{array}$ & [127] \\
\hline
\end{tabular}

* The highest yield obtained. 


\section{Challenges and Future Recommendations}

There is currently an issue with agro-industrial waste disposal across the world. Therefore, it is vital to continuously explore for alternatives to manage the problem effectively. A review of recent advances in the effect of different pretreatment techniques on the conversion of natural fibres to bioproducts has been discussed. It can be inferred that the downstream application has a profound effect on the selection and optimization of a feasible pretreatment technique. Among all of these, non-chemical approaches for natural fibres pretreatment are gaining popularity since they are more advantageous and greener than chemical pretreatment due to their chemical-free processability, cost-effectiveness, and sustainability. This is due to the fact that an ideal natural fibres pretreatment should have minimum or no solvent costs and also the capacity to process at high solids loadings with shorter treatment times and minimal inhibitor formation.

In fact, each pretreatment has its own set of limitations or shortcomings, and no specific technique can be used to pretreat all types of biomasses. Hence, a thorough understanding of the relationship between biomass structure and pretreatment is needed. Each pretreatment has a substantial impact on fibre properties. The selection of pretreatment is determined by the widespread application of natural fibre materials. Several factors such as type of fibre, crystallinity, molecular weight and other properties may influence in selecting the most effective pretreatment method. Additionally, operating conditions, such as temperature, time, etc must be taken into consideration during pretreatments as they have a direct influence on the fibre properties.

As mentioned previously, each pretreatment method has its benefits and shortcomings depending on the source of biomass, the processes employed, and the desired end product. Nevertheless, many previous studies have been conducted on a small scale, yet there is a significant disparity between laboratory preliminary findings, pilot-scale outcomes, and, eventually, industrial-scale results. Hence, further research is needed to address these issues and provide a feasible pretreatment approach for large-scale biorefinery operations.

Besides that, utilization of by-products derived from the pretreatment is also important to be investigated. For example, the SHS pretreatment had partially degraded the lignocellulosic structure of the biomass into smaller compounds such as acetic acid, formic, levulinic and succinic. These compounds were found useful to be used as antimicrobial agents. This indicates the possibility of having lignocellulosic components degradation products as byproducts during SHS pretreatment [33]. However, to the best of our knowledge, lack of reports was focused on the other type of pretreatments. Moreover, it is also important to ensure that there is no consequence generation of contaminants could be derived during the pretreatment process of fibres.

Even though most of the non-chemical pretreatment as discussed here are known to be more environmentally friendly, improvements are still needed. This is due to the fact that some of the techniques such as milling, SHS, and hydrothermal pretreatment require high production cost, especially at industrial levels. The high energy consumption and long processing time related to the pretreatment of fibres is still an issue that hampers the industrial applicability of some of these pretreatments. However, to the best of our knowledge, progress has been accomplished in this area, and numerous studies to overcome this issue have now been conducted worldwide.

Author Contributions: Conceptualization, M.N.F.N., M.R.M.H., M.A.A.F., S.S.S., M.S.M.M. and T.A.T.Y.-A.; validation, J.N. and N.M.N.; writing-original draft preparation, M.N.F.N., M.R.M.H., M.A.A.F., S.S.S., M.S.M.M., T.A.T.Y.-A. and M.I.H.; supervision, R.A.I., and M.A.J.; project administration, M.S.A.R. and M.I.H.; funding acquisition, M.R.M.H. All authors have read and agreed to the published version of the manuscript.

Funding: This research received no external funding and The APC was funded by Universiti Putra Malaysia (UPM).

Institutional Review Board Statement: Not applicable. 
Informed Consent Statement: Not applicable.

Data Availability Statement: Not applicable.

Acknowledgments: The authors gratefully acknowledge the technical and financial support from the Universiti Putra Malaysia (UPM).

Conflicts of Interest: There are no conflict of interest to declare.

\section{References}

1. Aftab, M.N.; Iqbal, I.; Riaz, F.; Karadag, A.; Tabatabaei, M. Different Pretreatment Methods of Lignocellulosic Biomass for Use in Biofuel Production. In Biomass for Bioenergy-Recent Trends and Future Challenges; IntechOpen: London, UK, 2019.

2. Xiao, C.; Bolton, R.; Pan, W. Lignin from rice straw Kraft pulping: Effects on soil aggregation and chemical properties. Bioresour. Technol. 2007, 98, 1482-1488. [CrossRef]

3. Himmel, M.E.; Ding, S.-Y.; Johnson, D.K.; Adney, W.S.; Nimlos, M.R.; Brady, J.W.; Foust, T.D. Biomass Recalcitrance: Engineering Plants and Enzymes for Biofuels Production. Science 2007, 315, 804-807. [CrossRef]

4. Tu, W.-C.; Hallett, J.P. Recent advances in the pretreatment of lignocellulosic biomass. Curr. Opin. Green Sustain. Chem. 2019, 20, 11-17. [CrossRef]

5. Nurazzi, N.M. Treatments of natural fiber as reinforcement in polymer composites-A short review. Funct. Compos. Struct. 2021, 3, 2. [CrossRef]

6. Norrahim, M.N.F.; Ilyas, R.A.; Nurazzi, N.M.; Rani, M.S.A.; Atikah, M.S.N.; Shazleen, S.S. Chemical Pretreatment of Lignocellulosic Biomass for the Production of Bioproducts: An Overview. Appl. Sci. Eng. Prog. 2021. [CrossRef]

7. Williams, C.L.; Emerson, R.M.; Tumuluru, J.S. Biomass Compositional Analysis for Conversion to Renewable Fuels and Chemicals. In Biomass Volume Estimation and Valorization for Energy; IntechOpen Limited: London, UK, 2017. [CrossRef]

8. Mood, S.H.; Golfeshan, A.H.; Tabatabaei, M.; Jouzani, G.S.; Najafi, G.; Gholami, M.; Ardjmand, M. Lignocellulosic biomass to bioethanol, a comprehensive review with a focus on pretreatment. Renew. Sustain. Energy Rev. 2013, 27, 77-93. [CrossRef]

9. Guerriero, G.; Hausman, J.F.; Strauss, J.; Ertan, H.; Siddiqui, K.S. Lignocellulosic biomass: Biosynthesis, degradation, and industrial utilization. Eng. Life Sci. 2016, 16, 1-16. [CrossRef]

10. Barakat, A.; De Vries, H.; Rouau, X. Dry fractionation process as an important step in current and future lignocellulose biorefineries: A review. Bioresour. Technol. 2013, 134, 362-373. [CrossRef]

11. Chen, H.; Liu, J.; Chang, X.; Chen, D.; Xue, Y.; Liu, P.; Lin, H.; Han, S. A review on the pretreatment of lignocellulose for high-value chemicals. Fuel Process. Technol. 2017, 160, 196-206. [CrossRef]

12. Koupaie, E.h.; Dahadha, S.; Lakeh, A.A.B.; Azizi, A.; Elbeshbishy, E. Enzymatic pretreatment of lignocellulosic biomass for enhanced biomethane production-A review. J. Environ. Manag. 2019, 233, 774-784. [CrossRef]

13. Haldar, D.; Purkait, M.K. A review on the environment-friendly emerging techniques for pretreatment of lignocellulosic biomass: Mechanistic insight and advancements. Chemosphere 2021, 264, 128523. [CrossRef]

14. Zadeh, Z.E.; Abdulkhani, A.; Aboelazayem, O.; Saha, B. Recent Insights into Lignocellulosic Biomass Pyrolysis: A Critical Review on Pretreatment, Characterization, and Products Upgrading. Processes 2020, 8, 799. [CrossRef]

15. Mahmood, H.; Moniruzzaman, M.; Iqbal, T.; Khan, M.J. Recent advances in the pretreatment of lignocellulosic biomass for biofuels and value-added products. Curr. Opin. Green Sustain. Chem. 2019, 20, 18-24. [CrossRef]

16. Hassan, S.; Williams, G.A.; Jaiswal, A.K. Emerging technologies for the pretreatment of lignocellulosic biomass. Bioresour. Technol. 2018, 262, 310-318. [CrossRef]

17. Kumar, A.K.; Sharma, S. Recent updates on different methods of pretreatment of lignocellulosic feedstocks: A review. Bioresour. Bioprocess. 2017, 4, 1-19. [CrossRef]

18. Karunanithy, C.T.; Muthukumarappan, K. Influence of Extruder Temperature and Screw Speed on Pretreatment of Corn Stover while Varying Enzymes and Their Ratios. Appl. Biochem. Biotechnol. 2010, 162, 264-279. [CrossRef]

19. Zhu, J.; Wang, G.; Pan, X.; Gleisner, R. Specific surface to evaluate the efficiencies of milling and pretreatment of wood for enzymatic saccharification. Chem. Eng. Sci. 2009, 64, 474-485. [CrossRef]

20. Hideno, A.; Inoue, H.; Tsukahara, K.; Fujimoto, S.; Minowa, T.; Inoue, S.; Endo, T.; Sawayama, S. Wet disk milling pretreatment without sulfuric acid for enzymatic hydrolysis of rice straw. Bioresour. Technol. 2009, 100, 2706-2711. [CrossRef]

21. Bussemaker, M.J.; Zhang, D. Effect of Ultrasound on Lignocellulosic Biomass as a Pretreatment for Biorefinery and Biofuel Applications. Ind. Eng. Chem. Res. 2013, 52, 3563-3580. [CrossRef]

22. Gogate, P.R.; Sutkar, V.S.; Pandit, A.B. Sonochemical reactors: Important design and scale up considerations with a special emphasis on heterogeneous systems. Chem. Eng. J. 2011, 166, 1066-1082. [CrossRef]

23. Sanjay, M.R.; Siengchin, S.; Parameswaranpillai, J.; Jawaid, M.; Pruncu, C.I.; Khan, A. A comprehensive review of techniques for natural fibers as reinforcement in composites: Preparation, processing and characterization. Carbohydr. Polym. 2019, 207, 108-121. [CrossRef]

24. Bleuze, L.; Lashermes, G.; Alavoine, G.; Recous, S.; Chabbert, B. Tracking the dynamics of hemp dew retting under controlled environmental conditions. Ind. Crop. Prod. 2018, 123, 55-63. [CrossRef]

25. Fila, G.; Manici, L.M.; Caputo, F. In vitro evaluation of dew-retting of flax by fungi from southern Europe. Ann. Appl. Biol. 2001, 138, 343-351. [CrossRef] 
26. Repečkiene, J.; Jankauskiene, Z. Application of fungal complexes to improve flax dew-retting. Biomed. Moksl. 2009, 83, 63-71.

27. Jankauskiene, Z.; Lugauskas, A.; Repeckiene, J. New Methods for the Improvement of Flax Dew Retting. J. Nat. Fibers 2007, 3, 59-68. [CrossRef]

28. Liu, M.; Ale, M.T.; Kołaczkowski, B.; Fernando, D.; Daniel, G.; Meyer, A.S.; Thygesen, A. Comparison of traditional field retting and Phlebia radiata Cel 26 retting of hemp fibres for fibre-reinforced composites. AMB Express 2017, 7, 1-15. [CrossRef]

29. Fernando, D.; Thygesen, A.; Meyer, A.S.; Daniel, G. Elucidating field retting mechanisms of hemp fibres for biocomposites: Effects of microbial actions and interactions on the cellular micro-morphology and ultrastructure of hemp stems and bast fibres. BioResources 2019, 14, 4047-4084. [CrossRef]

30. Farid, M.A.A.; Hassan, M.A.; Roslan, A.M.; Ariffin, H.; Norrrahim, M.N.F.; Othman, M.R.; Yoshihito, S. Improving the decolorization of glycerol by adsorption using activated carbon derived from oil palm biomass. Environ. Sci. Pollut. Res. 2021, 28, 27976-27987. [CrossRef]

31. Norrrahim, M.N.F. Superheated Steam Pretreatment of Oil Palm Biomass for Improving Nanofibrillation of Cellulose and Performance of Polypropylene/Cellulose Nanofiber Composites. Doctoral Thesis, Universiti Putra Malaysia, Selangor, Malaysia, 2018.

32. Nordin, N.I.A.A.; Ariffin, H.; Andou, Y.; Hassan, M.A.; Shirai, Y.; Nishida, H.; Yunus, W.M.Z.W.; Karuppuchamy, S.; Ibrahim, N.A. Modification of Oil Palm Mesocarp Fiber Characteristics Using Superheated Steam Treatment. Molecules 2013, 18, $9132-9146$. [CrossRef]

33. Sharip, N.S.; Ariffin, H.; Hassan, M.A.; Nishida, H.; Shirai, Y. Characterization and application of bioactive compounds in oil palm mesocarp fiber superheated steam condensate as an antifungal agent. RSC Adv. 2016, 6, 84672-84683. [CrossRef]

34. Megashah, L.N.; Ariffin, H.; Zakaria, M.R.; Hassan, M.A.; Andou, Y.; Padzil, F.N.M. Modification of cellulose degree of polymerization by superheated steam treatment for versatile properties of cellulose nanofibril film. Cellulose 2020, 27, 7417-7429. [CrossRef]

35. Bahrin, E.K.; Baharuddin, A.S.; Ibrahim, M.F.; Razak, M.N.A.; Sulaiman, A.; Aziz, S.A.; Hassan, M.A.; Shirai, Y.; Nishida, H. Physicochemical property changes and enzymatic hydrolysis enhancement of oil palm empty fruit bunches treated with superheated steam. BioResources 2012, 7, 1784-1801. [CrossRef]

36. Norrahim, M.N.F.; Ariffin, H.; Hassan, M.A.; Ibrahim, N.A.; Yunus, W.M.Z.W.; Nishida, H. Utilisation of superheated steam in oil palm biomass pretreatment process for reduced chemical use and enhanced cellulose nanofibre production. Int. J. Nanotechnol. 2019, 16, 668. [CrossRef]

37. Norrahim, M.; Ariffin, H.; Yasim-Anuar, T.; Hassan, M.; Ibrahim, N.; Yunus, W.; Nishida, H. Performance Evaluation of Cellulose Nanofiber with Residual Hemicellulose as a Nanofiller in Polypropylene-Based Nanocomposite. Polymers 2021, 13, 1064. [CrossRef]

38. Zakaria, M.R.; Norrrahim, M.N.F.; Hirata, S.; Hassan, M.A. Hydrothermal and wet disk milling pretreatment for high conversion of biosugars from oil palm mesocarp fiber. Bioresour. Technol. 2015, 181, 263-269. [CrossRef] [PubMed]

39. Norrahim, M.N.F.; Ariffin, H.; Yasim-Anuar, T.A.T.; Ghaemi, F.; Hassan, M.A.; Ibrahim, N.A.; Ngee, J.L.H.; Yunus, W.M.Z.W. Superheated steam pretreatment of cellulose affects its electrospinnability for microfibrillated cellulose production. Cellulose 2018, 25, 3853-3859. [CrossRef]

40. Warid, M.N.M.; Ariffin, H.; Hassan, M.A.; Shirai, Y. Optimization of Superheated Steam Treatment to Improve Surface Modification of Oil Palm Biomass Fiber. Bioresources 2016, 11, 5780-5796. [CrossRef]

41. Lei, H.; Cybulska, I.; Julson, J. Hydrothermal Pretreatment of Lignocellulosic Biomass and Kinetics. J. Sustain. Bioenergy Syst. 2013, 3, 250-259. [CrossRef]

42. Lee, J.; Park, K.Y. Impact of hydrothermal pretreatment on anaerobic digestion efficiency for lignocellulosic biomass: Influence of pretreatment temperature on the formation of biomass-degrading byproducts. Chemosphere 2020, 256, 127116. [CrossRef]

43. Zakaria, M.R.; Hirata, S.; Hassan, M.A. Hydrothermal pretreatment enhanced enzymatic hydrolysis and glucose production from oil palm biomass. Bioresour. Technol. 2015, 176, 142-148. [CrossRef]

44. Rasmussen, H.; Sørensen, H.R.; Meyer, A.S. Formation of degradation compounds from lignocellulosic biomass in the biorefinery: Sugar reaction mechanisms. Carbohydr. Res. 2014, 385, 45-57. [CrossRef]

45. Bianco, F.; Şenol, H.; Papirio, S. Enhanced lignocellulosic component removal and biomethane potential from chestnut shell by a combined hydrothermal-alkaline pretreatment. Sci. Total. Environ. 2021, 762, 144178. [CrossRef]

46. Zhang, H.; Li, J.; Huang, G.; Yang, Z.; Han, L. Understanding the synergistic effect and the main factors influencing the enzymatic hydrolyzability of corn stover at low enzyme loading by hydrothermal and/or ultrafine grinding pretreatment. Bioresour. Technol. 2018, 264, 327-334. [CrossRef] [PubMed]

47. Phuttaro, C.; Sawatdeenarunat, C.; Surendra, K.; Boonsawang, P.; Chaiprapat, S.; Khanal, S.K. Anaerobic digestion of hydrothermally-pretreated lignocellulosic biomass: Influence of pretreatment temperatures, inhibitors and soluble organics on methane yield. Bioresour. Technol. 2019, 284, 128-138. [CrossRef]

48. Megashah, L.N. Development of Efficient Processing Method for the Production of Cellulose Nanofibrils from Oil Palm Biomass. Doctoral Thesis, Universiti Putra Malaysia, Selangor, Malaysia, 2020.

49. Sarker, T.R.; Pattnaik, F.; Nanda, S.; Dalai, A.K.; Meda, V.; Naik, S. Hydrothermal pretreatment technologies for lignocellulosic biomass: A review of steam explosion and subcritical water hydrolysis. Chemosphere 2021, 284, 131372. [CrossRef] 
50. Marques, F.P.; Soares, A.K.L.; Lomonaco, D.; e Silva, L.M.A.; Santaella, S.T.; Rosa, M.D.F.; Leitão, R.C. Steam explosion pretreatment improves acetic acid organosolv delignification of oil palm mesocarp fibers and sugarcane bagasse. Int. J. Biol. Macromol. 2021, 175, 304-312. [CrossRef]

51. Medina, J.D.C.; Woiciechowski, A.; Filho, A.Z.; Nigam, P.S.; Ramos, L.P.; Soccol, C.R. Steam explosion pretreatment of oil palm empty fruit bunches (EFB) using autocatalytic hydrolysis: A biorefinery approach. Bioresour. Technol. 2016, 199, 173-180. [CrossRef]

52. Abraham, E.; Deepa, B.; Pothan, L.A.; Jacob, M.; Thomas, S.; Cvelbar, U.; Anandjiwala, R. Extraction of nanocellulose fibrils from lignocellulosic fibres: A novel approach. Carbohydr. Polym. 2011, 86, 1468-1475. [CrossRef]

53. Marques, F.P.; Silva, L.M.A.; Lomonaco, D.; Rosa, M.D.F.; Leitão, R.C. Steam explosion pretreatment to obtain eco-friendly building blocks from oil palm mesocarp fiber. Ind. Crop. Prod. 2020, 143, 111907. [CrossRef]

54. Meenakshisundaram, S.; Fayeulle, A.; Leonard, E.; Ceballos, C.; Pauss, A. Fiber degradation and carbohydrate production by combined biological and chemical/physicochemical pretreatment methods of lignocellulosic biomass-A review. Bioresour. Technol. 2021, 331, 125053. [CrossRef]

55. Ariffin, H.; Norrahim, M.N.F.; Yasim-Anuar, T.A.T.; Nishida, H.; Hassan, M.A.; Ibrahim, N.A.; Yunus, W.M.Z.W. Oil Palm Biomass Cellulose-Fabricated Polylactic Acid Composites for Packaging Applications. In Bionanocomposites for Packaging Applications; Springer Science and Business Media LLC.: Berlin, Germany, 2017; pp. 95-105.

56. Ilyas, R.; Sapuan, S.; Nurazzi, N.M.; Norrrahim, M.N.F.; Ibrahim, R.; Atikah, M.; Huzaifah, M.; Radzi, A.; Izwan, S.; Azammi, A.N.; et al. Macro to nanoscale natural fiber composites for automotive components: Research, development, and application. In Biocomposite and Synthetic Composites for Automotive Applications; Elsevier BV: Amsterdam, The Netherlands, $2021 ;$ pp. 51-105.

57. Ilyas, R.; Sapuan, S.; Harussani, M.; Hakimi, M.; Haziq, M.; Atikah, M.; Asyraf, M.; Ishak, M.; Razman, M.; Nurazzi, N.; et al. Polylactic Acid (PLA) Biocomposite: Processing, Additive Manufacturing and Advanced Applications. Polymers 2021, $13,1326$. [CrossRef]

58. Sharip, N.S.; Yasim-Anuar, T.A.T.; Norrrahim, M.N.F.; Shazleen, S.S.; Nurazzi, N.M.; Sapuan, S.M.; Ilyas, R.A. A Review on Nanocellulose Composites in Biomedical Application. In Composites in Biomedical Applications; CRC Press: Boca Raton, FL, USA, 2020; pp. 161-190.

59. Norrrahim, M.N.F.; Kasim, N.A.M.; Knight, V.F.; Ujang, F.A.; Janudin, N.; Razak, M.A.I.A.; Shah, N.A.A.; Noor, S.A.M.; Jamal, S.H.; Ong, K.K.; et al. Nanocellulose: The next super versatile material for the military. Mater. Adv. 2021, 2, 1485-1506. [CrossRef]

60. Norrahim, M.N.F.; Kasim, N.A.M.; Knight, V.F.; Misenan, M.S.M.; Janudin, N.; Shah, N.A.A.; Kasim, N.; Yusoff, W.Y.W.; Noor, S.A.M.; Jamal, S.H.; et al. Nanocellulose: A bioadsorbent for chemical contaminant remediation. RSC Adv. 2021, 11, 7347-7368. [CrossRef]

61. Yasim-Anuar, T.A.T. Well-Dispersed Cellulose Nanofiber in Low Density Polyethylene Nanocomposite by Liquid-Assisted Extrusion. Polymers 2020, 12, 927. [CrossRef] [PubMed]

62. Norrahim, M.N.F.; Nurazzi, N.M.; Jenol, M.A.; Farid, M.A.A.; Janudin, N.; Ujang, F.A.; Yasim-Anuar, T.A.T.; Najmuddin, S.U.F.S.; Ilyas, R.A. Emerging development of nanocellulose as an antimicrobial material: An overview. Mater. Adv. 2021, 2, 3538-3551. [CrossRef]

63. Nurazzi, N.M.; Asyraf, M.R.M.; Rayung, M.; Norrrahim, M.N.F.; Shazleen, S.S.; Rani, M.S.A.; Shafi, A.R.; Aisyah, H.A.; Radzi, M.H.M.; Sabaruddin, F.A.; et al. Thermogravimetric Analysis Properties of Cellulosic Natural Fiber Polymer Composites: A Review on Influence of Chemical Treatments. Polymers 2021, 13, 2710. [CrossRef]

64. Norrrahim, M.N.F. Cationic Nanocellulose as Promising Candidate for Filtration Material of COVID-19: A Perspective. Appl. Sci. Eng. Prog. 2021. [CrossRef]

65. Norrahim, M.N.F.; Yasim-Anuar, T.A.T.; Sapuan, S.; Ilyas, R.; Hakimi, M.I.; Najmuddin, S.U.F.S.; Jenol, M.A. Nanocellulose Reinforced Polypropylene and Polyethylene Composite for Packaging Application. In Bio-based Packaging; Wiley: Hoboken, NJ, USA, 2021; pp. 133-150.

66. Lee, C.H.; Lee, S.H.; Padzil, F.N.M.; Ainun, Z.M.A.; Norrrahim, M.N.F.; Chin, K.L. Biocomposites and Nanocomposites. In Composite Materials; Informa UK Limited: London, UK, 2021; pp. 29-60.

67. Nurazzi, N.; Asyraf, M.; Athiyah, S.F.; Shazleen, S.; Rafiqah, S.; Harussani, M.; Kamarudin, S.; Razman, M.; Rahmah, M.; Zainudin, E.; et al. A Review on Mechanical Performance of Hybrid Natural Fiber Polymer Composites for Structural Applications. Polymers 2021, 13, 2170. [CrossRef]

68. Nurazzi, N.; Asyraf, M.; Khalina, A.; Abdullah, N.; Aisyah, H.; Rafiqah, S.; Sabaruddin, F.; Kamarudin, S.; Norrrahim, M.; Ilyas, R.; et al. A Review on Natural Fiber Reinforced Polymer Composite for Bullet Proof and Ballistic Applications. Polymers 2021, 13, 646. [CrossRef]

69. Agbor, V.B.; Cicek, N.; Sparling, R.; Berlin, A.; Levin, D.B. Biomass pretreatment: Fundamentals toward application. Biotechnol. Adv. 2011, 29, 675-685. [CrossRef]

70. Moset, V.; Xavier, C.D.A.N.; Feng, L.; Wahid, R.; Møller, H. Combined low thermal alkali addition and mechanical pre-treatment to improve biogas yield from wheat straw. J. Clean. Prod. 2018, 172, 1391-1398. [CrossRef]

71. Khan, A.S.; Man, Z.; Bustam, M.A.; Kait, C.F.; Khan, M.I.; Muhammad, N.; Nasrullah, A.; Ullah, Z.; Ahmad, P. Impact of Ball-Milling Pretreatment on Pyrolysis Behavior and Kinetics of Crystalline Cellulose. Waste Biomass-Valorization 2016, 7, 571-581. [CrossRef] 
72. Zhu, J.Y.; Pan, X.; Zalesny, R.S. Pretreatment of woody biomass for biofuel production: Energy efficiency, technologies, and recalcitrance. Appl. Microbiol. Biotechnol. 2010, 87, 847-857. [CrossRef] [PubMed]

73. Jędrzejczyk, M.; Soszka, E.; Czapnik, M.; Ruppert, A.M.; Grams, J. Physical and Chemical Pretreatment of Lignocellulosic Biomass. In Second and Third Generation of Feedstocks: The Evolution of Biofuels; Elsevier: Amsterdam, The Netherlands, 2019 ; pp. 143-196. [CrossRef]

74. De la Rubia, M.A.; Fernández-Cegrí, V.; Raposo, F.; Borja, R. Influence of particle size and chemical composition on the performance and kinetics of anaerobic digestion process of sunflower oil cake in batch mode. Biochem. Eng. J. 2011, 58-59, 162-167. [CrossRef]

75. Ramos, L.P. The chemistry involved in the steam treatment of lignocellulosic materials. Quimica Nova 2003, 26, 863-871. [CrossRef]

76. Takács, E.; Wojnárovits, L.; Földváry, C.; Hargittai, P.; Borsa, J.; Sajó, I. Effect of combined gamma-irradiation and alkali treatment on cotton-cellulose. Radiat. Phys. Chem. 2000, 57, 399-403. [CrossRef]

77. Naimi, L.J.; Sokhansanj, S. Data-based equation to predict power and energy input for grinding wheat straw, corn stover, switchgrass, miscanthus, and canola straw. Fuel Process. Technol. 2018, 173, 81-88. [CrossRef]

78. Pérez-Rodríguez, N.; García-Bernet, D.; Domínguez, J.M. Faster methane production after sequential extrusion and enzymatic hydrolysis of vine trimming shoots. Environ. Chem. Lett. 2018, 16, 295-299. [CrossRef]

79. Zhang, S.-C.; Lai, Q.-H.; Lu, Y.; Liu, Z.-D.; Wang, T.; Zhang, C.; Xing, X.-H. Enhanced biohydrogen production from corn stover by the combination of Clostridium cellulolyticum and hydrogen fermentation bacteria. J. Biosci. Bioeng. 2016, 122, $482-487$. [CrossRef]

80. He, L.; Huang, H.; Lei, Z.; Liu, C.; Zhang, Z. Enhanced hydrogen production from anaerobic fermentation of rice straw pretreated by hydrothermal technology. Bioresour. Technol. 2014, 171, 145-151. [CrossRef]

81. Baeta, B.; Lima, D.R.S.; Adarme, O.F.H.; Gurgel, L.; de Aquino, S.F. Optimization of sugarcane bagasse autohydrolysis for methane production from hemicellulose hydrolyzates in a biorefinery concept. Bioresour. Technol. 2016, 200, 137-146. [CrossRef]

82. Jackowiak, D.; Bassard, D.; Pauss, A.; Ribeiro, T. Optimisation of a microwave pretreatment of wheat straw for methane production. Bioresour. Technol. 2011, 102, 6750-6756. [CrossRef]

83. Li, L.; Kong, X.; Yang, F.; Li, D.; Yuan, Z.; Sun, Y. Biogas Production Potential and Kinetics of Microwave and Conventional Thermal Pretreatment of Grass. Appl. Biochem. Biotechnol. 2012, 166, 1183-1191. [CrossRef] [PubMed]

84. Simona, M.; Gianfranco, A.; Jody, G.; Paolo, B. Energetic assessment of extrusion as pre-treatment to improve the anaerobic digestion of agricultural ligno-cellulosic biomasses. In Proceedings of the 15th International Conference Ramiran 2013, Versailles, France, 3-5 June 2013; Volume 1.

85. Bauer, A.; Lizasoain, J.; Theuretzbacher, F.; Agger, J.W.; Rincón, M.; Menardo, S.; Saylor, M.K.; Enguídanos, R.; Nielsen, P.J.; Potthast, A.; et al. Steam explosion pretreatment for enhancing biogas production of late harvested hay. Bioresour. Technol. 2014, 166, 403-410. [CrossRef]

86. Alinia, R.; Zabihi, S.; Esmaeilzadeh, F.; Kalajahi, J.F. Pretreatment of wheat straw by supercritical CO2 and its enzymatic hydrolysis for sugar production. Biosyst. Eng. 2010, 107, 61-66. [CrossRef]

87. Chandra, R.P.; Chu, Q.; Hu, J.; Zhong, N.; Lin, M.; Lee, J.-S.; Saddler, J. The influence of lignin on steam pretreatment and mechanical pulping of poplar to achieve high sugar recovery and ease of enzymatic hydrolysis. Bioresour. Technol. 2016, 199, 135-141. [CrossRef]

88. DeMartini, J.D.; Foston, M.; Meng, X.; Jung, S.; Kumar, R.; Ragauskas, A.J.; Wyman, C.E. How chip size impacts steam pretreatment effectiveness for biological conversion of poplar wood into fermentable sugars. Biotechnol. Biofuels 2015, 8, 1-16. [CrossRef] [PubMed]

89. Walch, E.; Zemann, A.; Schinner, F.; Bonn, G.; Bobleter, O. Enzymatic saccharification of hemicellulose obtained from hydrothermally pretreated sugar cane bagasse and beech bark. Bioresour. Technol. 1992, 39, 173-177. [CrossRef]

90. Ståhl, M.; Nieminen, K.; Sixta, H. Hydrothermolysis of pine wood. Biomass-Bioenergy 2018, 109, 100-113. [CrossRef]

91. Pińkowska, H.; Krzywonos, M.; Wolak, P. Valorization of Rapeseed Meal by Hydrothermal Treatment-Effect of Reaction Parameters on Low Molecular Products Distribution. Cellul. Chem. Technol. 2019, 53, 755-765. [CrossRef]

92. Zhang, Y.; Chen, J.; Zhang, L.; Zhan, P.; Liu, N.; Wu, Z. Preparation of nanocellulose from steam exploded poplar wood by enzymolysis assisted sonication Preparation of nanocellulose from steam exploded poplar wood by enzymolysis assisted sonication. Mater. Res. Express 2020, 7, 035010. [CrossRef]

93. Wang, Y.; Wei, X.; Li, J.; Wang, Q.; Wang, F.; Kong, L. Homogeneous Isolation of Nanocellulose from Cotton Cellulose by High Pressure Homogenization. J. Mater. Sci. Chem. Eng. 2013, 1, 49-52. [CrossRef]

94. Li, J.; Wei, X.; Wang, Q.; Chen, J.; Chang, G.; Kong, L.; Su, J.; Liu, Y. Homogeneous isolation of nanocellulose from sugarcane bagasse by high pressure homogenization. Carbohydr. Polym. 2012, 90, 1609-1613. [CrossRef]

95. Hatakka, A. Pretreatment of wheat straw by white-rot fungi for enzymic saccharification of cellulose. Appl. Microbiol. Biotechnol. 1983, 18, 350-357. [CrossRef]

96. Çağrı, A.; Ince, O.; Bozan, M.; Ozbayram, G.; Ince, B. Biological pretreatment with Trametes versicolor to enhance methane production from lignocellulosic biomass: A metagenomic approach. Ind. Crop. Prod. 2019, 140. [CrossRef]

97. Chen, S.; Zhang, X.; Singh, D.; Yu, H.; Yang, X. Biological pretreatment of lignocellulosics: Potential, progress and challenges. Biofuels 2010, 1, 177-199. [CrossRef] 
98. Tanahashi, M. Characterization and degradation mechanisms of wood components by steam explosion and utilization of exploded wood. In Bulletin of the Wood Research Institute Kyoto University; Kyoto University Research Information Repository: Kyoto, Japan, 1990; Volume 77, pp. 49-117.

99. Gregg, D.; Saddler, J.N. A Techno-Economic Assessment of the Pretreatment and Fractionation Steps of a Biomass-to-Ethanol Process. In Seventeenth Symposium on Biotechnology for Fuels and Chemicals; Humana Press: Totowa, NJ, USA, 1996; Volume 57, pp. 711-727. [CrossRef]

100. De Souza, C.G.M.; Tychanowicz, G.K.; De Souza, D.F.; Peralta, R.M. Production of laccase isoforms byPleurotus pulmonarius in response to presence of phenolic and aromatic compounds. J. Basic Microbiol. 2004, 44, 129-136. [CrossRef]

101. Galbe, M.; Zacchi, G. A review of the production of ethanol from softwood. Appl. Microbiol. Biotechnol. 2002, 59, 618-628. [CrossRef]

102. Mtui, G.Y.S. Trends in industrial and environmental biotechnology research in Tanzania. Afr. J. Biotechnol. 2007, 6, 2860-2867. [CrossRef]

103. Ubalua, A.O. Cassava wastes: Treatment options and value addition alternatives. Afr. J. Biotechnol. 2007, 6, 2065-2073. [CrossRef]

104. Demirbaş, A. Utilization of Urban and Pulping Wastes to Produce Synthetic Fuel via Pyrolysis. Energy Sources 2002, 24, 205-213. [CrossRef]

105. Guerra, A.; Mendonça, R.; Ferraz, A. Molecular weight distribution of wood components extracted from Pinus taeda biotreated by Ceriporiopsis subvermispora. Enzym. Microb. Technol. 2003, 33, 12-18. [CrossRef]

106. Maijala, P.; Kleen, M.; Westin, C.; Poppius-Levlin, K.; Herranen, K.; Lehto, J.; Reponen, P.; Mäentausta, O.; Mettälä, A.; Hatakka, A. Biomechanical pulping of softwood with enzymes and white-rot fungus Physisporinus rivulosus. Enzym. Microb. Technol. 2008, 43, 169-177. [CrossRef]

107. Wan, C.; Li, Y. Microbial pretreatment of corn stover with Ceriporiopsis subvermispora for enzymatic hydrolysis and ethanol production. Bioresour. Technol. 2010, 101, 6398-6403. [CrossRef]

108. Oyeleke, S.B.; Dauda, B.E.N.; Oyewole, O.A.; Okoliegbe, I.N.; Ojebode, T. Production of bioethanol from cassava and sweet potato peels. Ad. Environ. Biol 2011, 5, 3729-3733.

109. Taha, M.; Shahsavari, E.; Al-Hothaly, K.; Mouradov, A.; Smith, A.; Ball, A.; Adetutu, E.M. Enhanced Biological Straw Saccharification Through Coculturing of Lignocellulose-Degrading Microorganisms. Appl. Biochem. Biotechnol. 2015, 175, 3709-3728. [CrossRef]

110. Song, L.; Yu, H.; Ma, F.; Zhang, X. Biological Pretreatment under Non-sterile Conditions for Enzymatic Hydrolysis of Corn Stover. Bioresources 2013, 8, 3802-3816. [CrossRef]

111. Du, W.; Yu, H.; Song, L.; Zhang, J.; Weng, C.; Ma, F.; Zhang, X. The promoting effect of byproducts from Irpex lacteus on subsequent enzymatic hydrolysis of bio-pretreated cornstalks. Biotechnol. Biofuels 2011, 4, 37. [CrossRef]

112. Zhang, Q.; He, J.; Tian, M.; Mao, Z.; Tang, L.; Zhang, J.; Zhang, H. Enhancement of methane production from cassava residues by biological pretreatment using a constructed microbial consortium. Bioresour. Technol. 2011, 102, 8899-8906. [CrossRef] [PubMed]

113. Passos, F.; Hom-Diaz, A.; Blanquez, P.; Vicent, T.; Ferrer, I. Improving biogas production from microalgae by enzymatic pretreatment. Bioresour. Technol. 2016, 199, 347-351. [CrossRef]

114. Ali, S.S.; Al-Tohamy, R.; Manni, A.; Luz, F.C.; Elsamahy, T.; Sun, J. Enhanced digestion of bio-pretreated sawdust using a novel bacterial consortium: Microbial community structure and methane-producing pathways. Fuel 2019, 254, 115604. [CrossRef]

115. Guo, H.; Zhao, Y.; Chen, X.; Shao, Q.; Qin, W. Pretreatment of Miscanthus with biomass-degrading bacteria for increasing delignification and enzymatic hydrolysability. Microb. Biotechnol. 2019, 12, 787-798. [CrossRef]

116. Machado, A.D.S.; Ferraz, A. Biological pretreatment of sugarcane bagasse with basidiomycetes producing varied patterns of biodegradation. Bioresour. Technol. 2017, 225, 17-22. [CrossRef]

117. Castoldi, R.; Bracht, A.; de Morais, G.R.; Baesso, M.L.; Corrêa, R.C.G.; Peralta, R.; Moreira, R.; Polizeli, M.D.L.; de Souza, C.G.M.; Peralta, R.M. Biological pretreatment of Eucalyptus grandis sawdust with white-rot fungi: Study of degradation patterns and saccharification kinetics. Chem. Eng. J. 2014, 258, 240-246. [CrossRef]

118. Kumar, M.N.; Ravikumar, R.; Sankar, M.K.; Thenmozhi, S. New insight into the effect of fungal mycelia present in the biopretreated paddy straw on their enzymatic saccharification and optimization of process parameters. Bioresour. Technol. 2018, 267, 291-302. [CrossRef]

119. Jagtap, S.; Dhiman, S.; Kim, T.-S.; Li, J.; Kang, Y.C.; Lee, J.-K. Characterization of a $\beta$-1,4-glucosidase from a newly isolated strain of Pholiota adiposa and its application to the hydrolysis of biomass. Biomass-Bioenergy 2013, 54, 181-190. [CrossRef]

120. Dhiman, S.S.; Haw, J.-R.; Kalyani, D.; Kalia, V.C.; Kang, Y.C.; Lee, J.-K. Simultaneous pretreatment and saccharification: Green technology for enhanced sugar yields from biomass using a fungal consortium. Bioresour. Technol. 2015, 179, 50-57. [CrossRef]

121. Jagtap, S.; Dhiman, S.; Kim, T.-S.; Li, J.; Lee, J.-K.; Kang, Y.C. Enzymatic hydrolysis of aspen biomass into fermentable sugars by using lignocellulases from Armillaria gemina. Bioresour. Technol. 2013, 133, 307-314. [CrossRef] [PubMed]

122. Zhu, J.Y.; Sabo, R.; Luo, X. Integrated production of nano-fibrillated cellulose and cellulosic biofuel (ethanol) by enzymatic fractionation of wood fibers. Green Chem. 2011, 13, 1339-1344. [CrossRef]

123. Henriksson, M.; Berglund, L.; Lindström, T. An environmentally friendly method for enzyme-assisted preparation of microfibrillated cellulose (MFC) nanofibers. Eur. Polym. J. 2007, 43, 3434-3441. [CrossRef]

124. Tsukamoto, J.; Durán, N.; Tasic, L. Nanocellulose and Bioethanol Production from Orange Waste using Isolated Microorganisms. J. Braz. Chem. Soc. 2013, 24, 1537-1543. [CrossRef] 
125. de Camargo, L.A.; Pereira, S.C.; Correa, A.C.; Farinas, C.S.; Marconcini, J.M.; Mattoso, L.H.C. Feasibility of Manufacturing Cellulose Nanocrystals from the Solid Residues of Second-Generation Ethanol Production from Sugarcane Bagasse. BioEnergy Res. 2016, 9, 894-906. [CrossRef]

126. Martelli-Tosi, M.; Torricillas, M.D.S.; Martins, M.A.; De Assis, O.B.G.; Tapia-Blácido, D.R. Using Commercial Enzymes to Produce Cellulose Nanofibers from Soybean Straw. J. Nanomater. 2016, 2016, 1-10. [CrossRef]

127. Beltramino, F.; Roncero, M.B.; Vidal, T.; Torres, A.L.; Valls, C. Increasing yield of nanocrystalline cellulose preparation process by a cellulase pretreatment. Bioresour. Technol. 2015, 192, 574-581. [CrossRef] [PubMed] 